\title{
REGULATING FINTECH IN CANADA AND THE UNITED STATES: COMPARISON, CHALLENGES AND OPPORTUNITIES*
}

Ryan Clements

\section{SUMMARY}

The rise of fintech has attracted increased attention from investors, entrepreneurs, existing financial-sector participants and regulators. Fintech has many potential benefits and it could transform banking, lending, payments, investing and other financial services through the internet, smartphones, artificial intelligence, blockchain and cryptocurrencies, and many other current and future digital technologies. Such benefits include lower costs, an enhanced scope of products and services, and the possibility of reaching and offering previously underserved customers greater credit and financial services. Policy makers in Canada and the U.S. should encourage these positive developments, foster innovation and competition, and reduce barriers to entry, while ensuring adequate safeguards are established for the stability of the financial system and necessary consumer protections are in place.

The market environment and regulatory approaches in Canada and the U.S. are similar but not uniform. Each jurisdiction faces different challenges and opportunities. The speed and complexity that this new wave of fintech has expanded throughout North America and the world, in just a few years, has created regulatory challenges for authorities in the U.S. and Canada. Fintech has many potential risks. If this revolution is not managed well, the results could be serious, including the risk of destabilizing the financial system.

In the U.S., fintech has the potential for displacing banks and established financial institutions. There is also significant regulatory fragmentation and a growing desire for "principles-based" regulation - away from the "rules" based frameworks which generally characterize U.S. financial oversight. Several federal

* This research was financially supported by the Government of Canada via a partnership with Western Economic Diversification. 
and state regulators have instituted "regulatory sandboxes," which are an innovation that allows fintech firms to experiment with financial products and services in a limited and supervised way with potential relief from otherwise strict rules.

Canada's financial regulatory structure is principles-based, and there is a healthy regulatory sandbox in securities jurisdiction. In Canada, due to high barriers to entry, and regulatory fragmentation for some fintech market segments not under federal oversight, fintech has been heavily driven by existing big banks. These incumbents often partner with upstart fintech firms to develop products and services inside the bank's existing infrastructure to enhance customer service and operations. As a result, new consumer-facing fintech firms in Canada are less prominent than in the U.S., which enjoys far greater levels of funding for fintech start-ups.

Fintech creates new types of risks. When banks internally adopt fintech innovations into their existing processes and services there is cyber-risk and customer data vulnerability through new interface technologies, and risk to the stability of the financial system if more riskier borrowers are quickly approved for credit using algorithmic processes. Banks partnering with technology companies must also monitor and manage third parties. This requires heightened due diligence and ongoing monitoring costs.

Fintech innovations promoted outside the big banks by new, consumer-facing firms present their own challenges. Among these are increased moral hazard in peer-to-peer lending, the move toward higher-speed transactions (such as faster loan approvals) increasing systemic risk, and the possibility of algorithmic investing advice causing investor herds, and increasing the fall-out from a potential crash in certain sectors or asset classes. There is also risk from decentralized fintech innovations - like the widespread adoption of payment tokens like Bitcoin - as well as from new capital raising processes like initial coin offerings. The challenge, therefore, to regulators of properly overseeing so many new and untested developments without stifling innovation and the availability of new products is formidable - and also somewhat daunting.

In both jurisdictions, policy makers must be mindful of fintech's unique risk propositions and its benefits; both when it's adopted internally by existing financial institutions under regulatory oversight, and when fintech originates from new, consumer-facing market entrants. They must also ensure that regulatory efforts are coordinated with international best-practices and be mindful of any potential unintended effects of regulatory action given an increasingly complex and interconnected financial market. 


\section{RÉGLEMENTER LA TECHNOLOGIE FINANCIĖRE AU CANADA ET AUX ÉTATS-UNIS : COMPARAISON, DÉFIS ET OCCASIONS*}

Ryan Clements

\section{RÉSUMÉ}

La montée en puissance de la technologie financière attire de plus en plus l'attention des investisseurs, des entrepreneurs, des acteurs actuels du secteur financier et des autorités de réglementation. La technologie financière présente de nombreux avantages et pourrait transformer la façon d'effectuer les opérations bancaires, les prêts, les paiements, les investissements ou autres, et ce, grâce à l'Internet, aux téléphones intelligents, à l'intelligence artificielle, aux chaînes de blocs, aux cryptomonnaies ainsi qu'à de nombreuses autres technologies numériques actuelles et à venir. Les avantages comprennent une réduction des coûts, une gamme élargie de produits et de services de même que la possibilité d'offrir à des clients a uparavant mal desservis de meilleurs services financiers. Les responsables de politiques au Canada et aux États-Unis devraient encourager ces développements positifs, favoriser l'innovation et la concurrence, réduire les barrières d'accès et s'assurer que les garanties adéquates sont en place pour la stabilité du système financier ainsi que pour la protection des consommateurs.

L'environnement du marché et les méthodes de réglementation au Canada et aux États-Unis sont similaires mais pas uniformes. Chaque autorité fait face à différents défis et possibilités. La rapidité et la complexité avec lesquelles cette nouvelle vague de technologie financière s'est déployée en Amérique du Nord et dans le monde, en quelques années seulement, ont apporté des défis réglementaires pour les autorités américaines et canadiennes. La technologie financière comporte de nombreux risques potentiels. Si cette révolution n'est pas 
bien gérée, les résultats pourraient être graves et risqueraient notamment de déstabiliser le système financier.

Aux États-Unis, la technologie financière a le potentiel de perturber les banques et les institutions financières bien établies. Il y a également une fragmentation importante de la réglementation et un désir croissant d'une réglementation "axée sur les principes », loin des cadres habituels fondés sur les « règles » qui caractérisent généralement la surveillance financière aux États-Unis. Plusieurs organismes de réglementation fédéraux et étatiques ont institué des "bacs à sable réglementaires », une innovation qui permet aux entreprises de technologie financière d'expérimenter des produits et services financiers de manière limitée et supervisée, avec un allégement potentiel de règles par ailleurs strictes.

Au Canada, la structure de réglementation financière est fondée sur les principes et le secteur des valeurs mobilières dispose d'un bac à sable réglementaire sain. En raison des barrières d'accès élevées et de la fragmentation de la réglementation pour certains segments du marché de la technologie financière non soumis à la surveillance fédérale, la technologie financière au Canada est fortement influencée par les grandes banques établies. Ces acteurs s'associent souvent à des entreprises de technologies financières de pointe pour développer des produits et services au sein de l'infrastructure existante de la banque, afin d'améliorer les opérations et le service à la clientèle. Par conséquent, les nouvelles entreprises de technologie financière axées sur les consommateurs sont moins importantes au Canada qu'aux États-Unis, qui bénéficient de niveaux de financement beaucoup plus élevés pour les entreprises de technologie financière en démarrage.

La technologie financière apporte de nouveaux types de risques. En adoptant à l'interne technologie financière novatrices pour leurs processus et services déjà en place, les banques s'exposent au cyberrisque et à la vulnérabilité des données des clients en raison des nouvelles technologies d'interface. Elles s'exposent aussi à un risque en matière de stabilité du système financier si des emprunteurs plus risqués reçoivent rapidement l'approbation pour un crédit grâce aux processus algorithmiques. Les banques qui s'associent à des entreprises technologiques doivent également surveiller et gérer les tierces parties. Cela nécessite une diligence raisonnable accrue et des coûts de surveillance permanents.

Les technologies financières novatrices proposées en dehors des grandes banques par de nouvelles entreprises axées sur les consommateurs présentent leurs propres défis. Parmi ceux-ci, notons un risque moral accru dans les prêts entre pairs, le passage à des transactions plus rapides (telles que les approbations de prêts accélérées) qui augmentent le risque systémique et la possibilité de conseils d'investissement algorithmiques entraînant des hordes d'investisseurs et aggravant l'effet potentiel d'un crash dans certains secteurs ou classes d'actifs. II existe également un risque lié à la décentralisation des technologies financières novatrices, comme l'adoption généralisée de jetons de paiement comme le Bitcoin, ainsi qu'aux nouveaux processus de levée de capitaux tels que les premières émissions de cryptomonnaie. Par conséquent, les organismes de réglementation font face à un défi de taille quelque peu décourageant : superviser correctement autant de nouveaux développements non testés sans étouffer l'innovation ou la disponibilité de nouveaux produits. 
Dans les deux pays à l'étude, les décideurs doivent être conscients des possibilités de risque et des avantages de la technologie financière. Ces risques concernent à la fois l'adoption des technologies financières à l'interne par des institutions financières existantes assujetties à une surveillance réglementaire et la mise en place de ce type de technologie par de nouveaux venus sur le marché visant les consommateurs. Les décideurs doivent aussi veiller à ce que les efforts de réglementation soient coordonnés avec les pratiques internationales exemplaires et être conscients de tout effet indésirable potentiel des mesures de réglementation dans un marché financier de plus en plus complexe et interconnecté. 


\section{INTRODUCTION}

In the decade following the 2008 global financial crisis (GFC), smartphones and cellular access have become ubiquitous and advancements in artificial intelligence (AI) and data management have emerged alongside distributed ledger technology ("blockchain") and machine learning. These factors, together with the coming of age of a generation raised with the internet, has facilitated the integration of new technology into financial-market products, processes and services. This phenomenon is popularly called fintech (short for financial technology). Fintech is a promising development. It can lower the costs of financial services and products, enhance transaction speed and scope, increase credit access, and facilitate more efficient financial intermediation. However, it also poses unique new risks, not otherwise present in the financial system.

This article contrasts Canada's fintech industry and regulatory response against the United States. In the U.S. there is disintermediation potential and regulatory fragmentation under a rules-based framework, with a growing desire for principles-based supervision. Gaining prominence is the "regulatory sandbox" structure - a supervisory framework where fintech firms experiment with financial products and services, in a limited capacity, under regulatory oversight and relief. Canada has principles-based regulation and a national sandbox for fintech within security-regulatory jurisdiction. Fintech in Canada is also largely bank-driven, with many bank-tech partnerships. Regulators in both jurisdictions have the challenge of enacting policy guidelines, procedures and rules to mitigate fintech's unique new risks while ensuring stable and economically productive markets, a healthy ecosystem for ongoing innovation, and welfare-enhancing competition. Fragmentation exists in Canada for non-bank fintech firms that aren't federal financial institutions under the supervision of the Office of the Superintendent of Financial Institutions (OSFI) - such as non-bank peer-to-peer lending platforms or mobile-payments applications (Competition Bureau 2017, 49-63). Fragmentation isn't pervasive in Canada, however, because of the dominance of its large banks in financial services.

The article first defines fintech, notes its historical context, and documents its emergence. It then explores jurisdictional distinctions, unique fintech risks and regulatory responses and difficulties, such as agency overlap, and regulatory fragmentation. Next it surveys several fintech sub-sectors including banking, cryptocurrency and initial coin offerings (ICOS), fintech credit and marketplace lending, payments, robo-advisers and financial-account aggregators. Fintech also includes innovations like "insurtech," the marriage of insurance and technology, and "proptech," property technology that uses developments such as artificial intelligence, virtual reality and machine learning (Galea 2018). These developments, as well as traditional equity crowdfunding, are beyond the scope of this study. The article will conclude by noting the status of blockchain financial integration, regulatory technology ("regtech") rollouts, international regulatory co-operation initiatives, and areas of continuing research, including the challenge of regulating increasingly complex and interconnected financial markets. 


\section{DEFINING FINTECH: INTRODUCTION TO KEY CONCEPTS}

\section{FINTECH DEFINED: GENERAL OVERVIEW}

Fintech has diverse meanings. The Financial Stability Board has described it as "technologically enabled financial innovation that could result in new business models, applications, processes, or products with an associated material effect on financial markets and institutions and the provision of financial services" (Basel Committee 2018, 8). Fintech also captures any innovation that impacts a business or financial transaction (Kagan 2019). The Board of Governors of the Federal Reserve, in a report to the World Bank, defined fintech as "companies that use technology to make financial systems and the delivery of financial services more efficient" (Ancri 2016). Fintech includes products from new firms, driven by consumer demand for underserved markets, and innovations from banks that use new technology to enhance customer experience and make internal processes more efficient, such as credit-scoring algorithms for faster mortgage approval (Badour, Lynde and Firestone 2017) and infrastructure-support services, such as data and compliance systems (Gilroy 2017). Ernst and Young estimates that one-third of consumers worldwide used some form of fintech in 2017, and 84 per cent were aware of fintech products (CNBC 2017). This trend is also influenced by Bitcoin's historic price run (and crash) over the past two years (Chambers 2018). Fintech presents a dichotomy of benefit and risk. Competition in financial services can reduce costs, enhance the scope and benefits of financial products, and deepen credit markets by intermediating new investors with borrowers (Bailey 2018, 95). It can also enhance the consumer experience by developing better technological interfaces (Cutts and Roman, 2016, 1).

\section{FINTECH AS A HISTORICAL PHENOMENON}

Events like the 1866 transatlantic cable and the launch of automated teller machines in the late 1960s are also iterations of fintech (Douglas and Grinberg 2017, 669). Just as financial markets and products have evolved with the advent of information technology, so too has fintech. Other examples include financial-data management on mainframe computers and the rise of the internet and e-commerce, which created retail electronic banking and online securities trading (Desai 2015). A recent Basel Committee on Banking Supervision report $(2018,9)$ defined fintech as including both "sectoral innovations" and "market support services," with the former covering "credit, deposit, and capital raising services," "payments, clearing and settlement services," financial "investment management services," and market-support services, including "portal and data aggregators, ecosystems, data applications, distributed ledger technology, cybersecurity, cloud computing, Internet of things, and artificial intelligence." The largest sector noted was "payments, clearing and settlement services" (Basel Committee 2018,10 ). Fintech could also be an "antidote" to unproductive financial institution "rent-seeking" behaviour (Kidd 2018, 165). These explanations rely on a conventional economic-demand view of financial innovation, yet, some theorists consider financial innovation to be supply-driven and created by profit-seeking financial firms (Awrey 2012, 258-267). 


\section{POST-CRISIS PARADIGM, TECHNOLOGICAL DEVELOPMENTS AND KEY TRENDS}

The rise of fintech is a product of multiple factors, including distrust of financial institutions in the U.S. post-GFC (Arner, Barberis and Buckley 2016, 1318) and technology companies seeking out market segments with heightened post-GFC regulatory scrutiny (Zetzsche et al. 2017, 31). Fintech firms are pursuing customers that are historically underserved and more strictly regulated after the crisis (Rooney 2018). In both jurisdictions, the coming of age of a technologically savvy generation makes for rising demand (Hartmans 2016). The most important technology for fintech is a smartphone. According to a recent Pew Research Center report (2018), over 95 per cent of Americans own a cell phone, with 77 per cent having one capable of a fintech application. In Canada, recent estimates identify over 24 million people owning a smartphone in 2017 (Statista 2019). Another factor is changing customer behaviour and demand for "digital financial services" (Basel Committee 2018, 14). Also, age-shift dynamics heighten fintech interest as millennials and post-millennial "iGens" have begun using banking and financial services independent of their parents (Nonninger 2018).

Emerging trends also include development in fintech payments, algorithmic wealth management and investment advice ("robo-advisers"), online or peer-to-peer lending, and distributed-ledger technology-based products, with applications in both blockchain use cases and cryptocurrency (Stanley 2018). Other trends include voice-activated and "dueling" Al, fintech payment and banking interfacing with mobile-phone texting services, enhanced collaboration of innovators and regulators, more blockchain use cases, and an extended focus on products for lower-income individuals - commonly called the "financial inclusion" movement (CNBC 2018). Blockchain roll-outs for privacy and identity protection are also being investigated (Kimbrell 2018). A growing number of technology "incubators" or "accelerators" are providing business infrastructure and legal support for fintech startups and the banks that support these hubs often acquire the fintech firms (Walker 2017, 142, 145-146). The use of these and similar mechanisms, like bank-sponsored "in-house labs," "beachheads" and university institutional support help to accelerate fintech market integration and product take-up by consumers and financial institutions (Stikeman Elliot 2018).

\section{REGULATORY RESPONSE: IDENTIFYING GENERAL PRINCIPLES}

\section{GENERAL REGULATORY DIFFICULTIES AND JURISDICTIONAL DISTINCTIONS}

Fintech is a disruptive phenomenon with disintermediation potential for incumbent financial institutions (Brummer 2015, 977, 1020-1023). This presents many challenges and complexities for regulators. Depending on the firm, regulatory considerations extend to prudential matters (such as capital, liquidity and operational controls) market conduct, anti-trust, credit risk, and interconnection risk (Laplante and Watson 2018). It may also have implications for systemic risk (Petrou 2018). It clearly creates a vulnerability for cybersecurity, identity theft, privacy, criminal activity and data-breach risk (Waddell 2018). Also, as noted by the Competition Bureau of Canada (2017, 17), fintech companies 
may trigger a failure of "institutional governance, risks to consumers and investors, asymmetry of information (between financial services consumers and suppliers) and financial literacy, counterparty risks in payments."

There is a potential for an expertise differential given the speed of innovation and the slow pace of the legislative or rule-making process (Zetzsche et al. 2017, 38). Compounding this challenge is the issue of definitional clarity. For example, Blockchain technologies, and crypto-assets in general, are difficult to precisely define, and regulating them can facilitate inconsistent rules and "regulatory capture"; therefore, it's very challenging for a regulator to keep pace with disruption while simultaneously encouraging innovation (Walch 2017, 730-732). Regulators also do not want to enact bad rules with incomplete information, since poorly constructed regulations create new problems and "unsuitable regulatory frameworks" stifling innovation, competition and productivity growth (Chiu 2016, 111-112). This motivates a "do no harm" approach by the regulators (Tan 2018). Nevertheless, the failure to act is also risky because, as Hester Peirce, commissioner of the U.S. Securities and Exchange Commission, has identified, regulators are criticized when innovation harms investors (Peirce 2018). Yet onerous regulatory rules can drive "regulatory arbitrage" where firms seek out less rigorous jurisdictions to operate from (Panel on Fintech 2018).

The Canadian and U.S. fintech markets and regulatory frameworks have many similarities, but also key differences. The U.S. system of financial regulation is much more complex than Canada's, including more supervisory agencies (Jackson 2013; Savage 2014). Regulatory fragmentation is a much greater concern in the U.S. Canada has an "integrated" regulatory approach with a central financial regulator (the OSFI) for federal financial institutions (where most financial transactions occur) subject to a "consistent risk-assessment system" (Savage 2014, 44-45). Financial regulation in Canada is largely principles-based (Ford 2010; Pan 2011; Whitestone 2005), in contrast to the American regulatory model, which favours rules-based frameworks (Vartanian 2016). There is an appetite in the U.S. for a more principles-based approach (Deloitte 2015), and certain industry segments, such as derivatives, use them (Ford 2010, 6; Pan 2011, 840, 847). Despite a principles-based approach, Canada has been criticized for lagging in fintech development (Competition Bureau 2017, 4; Carmichael 2018). Also, adoption rates of non-bank fintech products in Canada is lower than global averages, including in the U.S. (Hinton et al. 2017, 2), and the U.S. has more venture funding for fintech startups than Canada does (PWC 2016, 9).

An explanation for the low number of new fintech market entrants in Canada is the stability of its major banks, who adopt fintech internally and compete directly with nonbank startups (PWC 2016). Also, customer-retention rates for Canadian banks are higher than their American counterparts (Watson and LaPlante 2018, 3). The dominant market position and risk-averse nature (Hinton et al. 2017, 2) of major Canadian banks may be a barrier to entry for smaller non-bank firms as the former can "use their economies of scale, resources, brand and expertise to compete" (PWC 2016, 11). Concentration of the financial services industry is much greater in Canada than in the U.S. (Hinton et al. 2017, 2). Also, because Canadians are used to dealing with a large bank, having customers transact with a non-bank fintech requires a "shift" in trust to the non-bank entity, which can be difficult to obtain (Hinton et al. 2017, 2). Recent studies identify that Canadian 
financial institutions engage in partnerships with fintech companies at a nine-percent higher rate than financial institutions in the United States and the Canadian rate is also 15-per-cent higher than the worldwide average (Watson and LaPlante 2018, 4). This highlights another important difference between the two jurisdictions: Canadian adoption of fintech tends to favour existing financial institutions utilizing technology to enhance customer service and operations, while the U.S. landscape has a greater proportion of consumer-facing new market entrants.

\section{AGENCY JURISDICTIONAL OVERLAP AND REGULATORY FRAGMENTATION}

A regulatory concern prominently featured in a recent report by the U.S. Government Accountability Office (2018) is overlapping jurisdiction between U.S. agencies causing conflicting guidance, fragmentation, and uncertainty regarding which agency has primary enforcement jurisdiction, as well as opaque consumer-grievance procedures. Depending on the actions a fintech firm undertakes, the nature of the firm itself, and the jurisdictions it operates in, it could be subject to a complex, fragmented and potentially conflicting array of federal, state and self-regulatory organization rules and requirements (GAO 2018). A fragmented regulatory structure can increase costs, stifle innovation, and produce ineffective regulation (GAO 2018). The U.S. Treasury Department (2018), in a recent fintech report, called for reduced fragmentation using "unified oversight structures," greater "regulatory co-operation," and the appointment of "primary" regulators for certain fintech industries. To help facilitate regulatory co-operation, the U.S. Federal Reserve also enacted, in March 2017, an "Interagency Fintech Discussion Forum" (Reiners 2018). Fragmentation in the U.S. is particularly relevant for marketplace lending, virtual currency, money transmission and securities (Knight 2017). It has been also argued that the U.S. lags in consumer financial technology because it lacks a unified "competition authority" (Van Loo 2018).

There is no single oversight body in Canada for fintech firms, and non-bank companies could be subject to regulation at both the provincial and federal level (Competition Bureau 2017, 6). The Competition Bureau (2017, 4-6) suggests that, as a result, "Canada lags behind its international peers when it comes to fintech adoption" and a "unified policy lead on fintech" should "combine federal, provincial and territorial expertise to facilitate fintech development and improve the scope and applicability of existing initiatives." Fragmentation in Canada does not exist when a bank internally adopts fintech since the OSFI is the primary bank regulator in Canada, and the vast majority of financial transactions in the country are conducted through banks (Sale 2018). Fragmentation and agency overlap have been identified by the Competition Bureau $(2017,49,63)$ and leading law firms (Borden Ladner Gervais 2016, 2; Dentons 2017) as an issue for nonbank, consumer-facing, fintech entrants including fintech-credit-lending platforms, robo-advisers and non-bank payment-processing companies that aren't subject to OSFI oversight. Non-bank fintech firms in Canada are, however, only a tiny proportion of the total market (Hinton, Lombardi and Wajda 2017, 2-3). Also, the area of consumer protection has been cited for non-bank fintech entrants as "an area of shared jurisdiction that is unnecessarily complex and lacks uniformity in many areas of relevance to fintech" and navigating this web of concurrent federal and provincial legislation can be both costly and a potential barrier to entry for new firms (Borden Ladner Gervais 2016, 4). 


\section{FINTECH'S UNIQUE NEW RISKS AND ASSOCIATED REGULATORY CONSIDERATIONS}

Fintech encompasses demand-driven, consumer-facing new entrants to the financial-services industry (such as non-bank peer-to-peer lending platforms, new cryptocurrencies, crowdsourced digital tokens as a means of enterprise fundraising, non-bank algorithmic wealth-management platforms, and downstream mobile "intranetwork" retail-payments innovations and digital wallets) (Competition Bureau 2017, 49). Fintech also encompasses technological innovations developed by (or for) existing financial institutions to enhance customer experience and make internal processes more efficient. The extent to which bank-adopted fintech introduces new instabilities hinges on whether new risks are not otherwise mitigated in existing regulatory frameworks. There is a potential for bank fintech to introduce new cyber risks (such as customer data loss or hacking) through new technology interfaces and online applications (McMillan 2016, 4). Also, technology that speeds up credit applications could fund more risky loans, and banks that adopt fintech through partnerships introduce costly "third-party/vendormanagement" risks with a new need for "due diligence, contract management, and continual monitoring of their party operations" (LaPlante and Watson 2018, 6).

Professor William Magnuson $(2018,1226)$ has argued that non-bank fintech firms introduce "new and different concerns than those presented by conventional financial institutions" given the interaction of "small disaggregated actors" and decentralized markets. He adds that disaggregated actors present a greater systemic risk to financial markets than "too-big-to-fail" financial institutions because small actors, with fewer resources, are "more vulnerable to adverse economic shocks" than are large banks (Magnuson 2018, 1171). Also, small consumer-facing firms are more difficult to monitor than large entities because of "opaque" operations and high information asymmetries (Magnuson 2018, 1203). Correspondingly, new firms generate a "collective action problem" that limits market-participant "co-operation" because smaller firms are "less restricted by reputational constraints," such as herding risk in algorithmic investmentmanagement programs (Magnuson 2018, 1199, 1209). Another concern is that new fintech firms can transact internationally through the internet, which necessitates greater crossborder regulatory co-ordination (Magnuson 2018, 1222-1223).

For non-bank fintech firms, another unique risk is that new entrants may provide similar products and services as those provided by heavily regulated entities, with reduced supervisory treatment, and in the process introduce instabilities into the financial system (Competition Bureau 2017, 2). Non-bank fintech peer-to-peer credit platforms could also induce what the Competition Bureau $(2017,47)$ describes as a disintermediating "principal-agent problem," in that "the platform may underprice risk or approve or facilitate loans to overly risky borrowers, collecting the origination fee while shifting the default risk entirely onto investors." Also, these platforms, which use non-traditional (and deeply guarded) credit-scoring algorithms, could engage in "investor redlining" and have a disparate impact on loan disapprovals for marginalized classes (Bailey 2018, 61; Ancri 2016, 21). Further, fintech loans that are sourced through non-bank portals could increase credit and cyber risk and liquidity concerns (Hinton, Lombardi and Wajda 2017, 4). Nonbank lending platforms may introduce "data movement" risks (such as screen scraping), 
accuracy risks in non-traditional credit-scoring algorithms, and opacity risks when nonbank lenders fail to report to credit-scoring agencies (Ancri 2016, 21). Further, just like regulated financial institutions, non-bank fintech firms introduce data-breach risks; however, unlike large banks, they may not have the financial resources to establish secure cyber-security protections (LaPlante and Watson 2018, 5).

New research from the U.S. shows that, for many of the largest ICOs of 2017, there is a computer-coding "disconnect" between the promises made by issuers in white papers and other marketing materials (such as token-vesting conditions, token-supply limits and code-modification rights) and the actual smart-contract code for the respective ICO (Cohney et al., forthcoming). Therefore, a unique fintech regulatory development is that securities supervisors, in both jurisdictions, must consider the costs and benefits of matching ICO disclosure materials to their corresponding smart-contract code (Cohney et al., forthcoming, 72). Additionally, cryptocurrency trading on an unregulated spot exchange can lead to consumer losses (from hacking and fraud) without compensation recourse (LaPlante and Watson 2018, 5). Another non-bank fintech-unique risk and regulatory concern is that payments applications, operating outside of traditional financial institutions, could drive more money laundering (McMillan 2016, 4). This stimulates the need for greater international regulatory co-ordination (LaPlante and Watson 2018, 8).

The extent that fintech will increase systemic risk is unknown (Bailey 2018, 81-83, 9294). It may be interconnecting institutions (both technology and financial) as well as consumers, and increasing contagion risk (LaPlante and Watson 2018, 7). Roboadvisers, which use exchange-traded funds in model portfolios, could exacerbate "procyclical" investor herding and increase volatility in a crisis, and also deepen "model risk" through correlated algorithms (LaPlante and Watson 2018, 8). Professor Saule Omarova (forthcoming, 55-58) argues that fintech has very unique and serious regulatory and systemic consequences that transcend the "transactional aspects of finance" that didn't previously exist before fintech. She points to cryptocurrency, blockchain and roboadvising, as amplifying the destabilizing impact of "synthesizing" financial assets and "scaling up" trading speed and volume, undermining the regulator's ability to respond effectively to system-wide risks (Omarova, forthcoming, 27, 28, 55-58).

\section{INTRODUCTION TO THE “REGULATORY SANDBOX” MODEL OF SUPERVISION}

A regulatory innovation gaining prominence in fintech is the "regulatory sandbox." A sandbox is a "safe space" where companies operate in a limited capacity and receive regulatory relief from traditional rules (for instance, no-action letters or waivers). The U.K.'s Financial Conduct Authority (FCA) was the first to embrace this regulatory model in an attempt to establish the U.K. as "the global capital of financial technology" (Barefoot 2016, 1). Regulators' willingness to engage with fintech firms on a "collaborative" basis through a sandbox may be due to an alignment of these firms' goals (lower fees, an enhanced user base for financial services and more efficient and secure transactions) with that of the regulator (a desire for economic development, enhanced competition, consumer protection, reduced conflicts and lower costs) (Borden Ladner Gervais 2016, 1; Stern 2017). Also, fintech firms are different than traditional "move-fast- 
and-break-things" Silicon Valley start-ups, such as Uber, which may use the legal process as a tool to solve business problems through strategic litigation or lobbying (Newcomer 2017). This strategy is unlikely in the financial industry because a fintech firm will encounter a powerful regulator with the ability to levy significant fines (Gavin et al. 2018).

In the U.S., in August 2018, Arizona became the first state to launch a sandbox for fintech (Finextra 2018). Additional states, such as Illinois, are considering similar initiatives (Kearns, Lorentz and Dempewolf 2018). At the federal-agency level, fintech sandboxes exist at both the Commodity Futures Trading Commission (LabCFTC) and the Consumer Financial Protection Bureau (CFPB) (Project Catalyst). The Office of the Comptroller of the Currency (OCC) has also established an Office of Innovation as a central contact for initiatives in the national banking sector. Also, the U.S. Treasury report (2018, 168) emphasized the need for sandboxes. A U.S. national sandbox is constitutionally uncertain, and unlike in the U.K., U.S. agencies don't have a competition-enhancing mandate (Reiners 2018). Sandboxes shouldn't be considered a panacea, however, and some officials - including SEC Commissioner Hester Peirce - have cautioned against regulators "sitting in the sandbox" with innovators and seeking to influence business decisions (Tonkovic 2018).

In Canada, a regulatory sandbox was initiated in 2017 by the Canadian Securities Administrators (CSA) as part of its 2016-19 business plan. Firms selected for the sandbox can test their products and services with a limited selection of the Canadian market and obtain "exemptive relief" from certain securities-law requirements (Canada Securities Administrators 2018). The Ontario government has announced its intention to create a regulatory "super sandbox" for fintech and launch an agency called the Ontario Fintech Accelerator Office to facilitate fintech innovation (Giovannetti 2017). There are also currently many private innovation accelerators in Canada, such as the DMZ-BMO Fintech Accelerator. Provincial securities commissions - including in Ontario, Quebec and British Columbia - have established advisory offices or working groups to support fintech growth (Stikeman Elliot 2018). The Alberta Securities Commission (2018) also established a "new economy" division focused on "issues and opportunities relating to emerging financial technologies."

\section{FINTECH BANKING}

\section{FINTECH BANKING AND PARTNERSHIP MODELS}

Some fintech firms may want to simply become banks, but this is not an overwhelming trend, and it's more relevant in the U.S. than in Canada (Rastello 2018). The complementary idea of integrated partnerships has become more prominent with banks using technology to augment existing services (Hannah 2018). Motivating this trend are both opportunity (expertise) and regulatory-cost considerations (Tweddle 2018). Another concern is that a bank must ensure that it has sufficient customer-data cyber-security protection in place and it must incur the cost of due diligence necessary to ensure such protection (Mirmazaheri 2016, 178). In becoming a bank, the benefits of low-cost funding (deposits) must be weighed against the costs of heightened regulatory scrutiny, the real application costs (and time) involved in obtaining a banking charter, and the daunting 
prospect of competing head to head with established institutions (Walsh 2018). In the U.S. there are multiple avenues of banking entry, including national banking charters, a new special purpose fintech charter, state charters and industrial loan company charters (recently applied for but subsequently withdrawn by fintech-credit company SoFi (Clozel 2017) and payments-processing company Square (Witkowski 2018)).

\section{U.S. FINTECH SPECIAL-PURPOSE BANKING CHARTER}

To operate as a bank in the U.S., a fintech needs to secure an appropriate national or state charter, which involves a rigorous and costly process. On July 31, 2018 the OCC (a prudential regulator) began accepting applications for "national bank charters from nondepository financial technology (fintech) companies engaged in the business of banking." Under the terms of this special-purpose charter, "( $f$ )intech companies that apply and qualify for, and receive, special purpose national bank charters will be supervised like similarly situated national banks, to include capital, liquidity, and financial inclusion commitments as appropriate"(OCC 2018). The cited benefits of the charter include "uniformity" and "transparency," as well as advancing the banking regulatory framework to facilitate innovation and new financial offerings outside of the conventional banking scope (Murphy 2017, 407-408). However, the announcement did not spur a rush of fintech bank applicants (Clozel 2018).

The OCC's fintech charter was initially opposed at the state level as being beyond the agency's jurisdictional authority (Savoie and Hoffman 2018, 511-512). The state of New York filed suit on Sept. 14, 2018 against the OCC, citing the fintech charter as both outside of the OCC's jurisdiction and "ill-conceived" (Dolmetsch 2018). New York's opposition to the fintech charter has been criticized since it would stifle an "emerging dual fintech system" (Curry and Cabral 2018). Other critics of the OCC's move cite the program's administrative (and application) burdens as so arduous and the benefits so limited (firms are subject to prudential controls including capital and liquidity commitments without the benefit of access to the Fed's payment system) that it won't be used at all (Baker 2018). Also, a fintech wanting to become a bank must obtain approval from the Federal Deposit Insurance Corp. (FDIC), and early indications from the FDIC charter application of mobile-banking company Varo Money (which recently pulled its initial FDIC application) show that obtaining FDIC approval won't be an easy step, if it can be obtained at all (Burns 2018).

\section{DEVELOPMENTS IN CANADIAN FINTECH BANKING}

The Canadian banking sector is dominated by a relatively few large national firms. The industry has high barriers to entry due to the significant transaction costs involved in switching banks, the constant addition of "features" that the big banks are providing, the difficulties for an upstart in obtaining a banking charter, and the significant reputational advantages of the big banks (Carmichael 2018). As a result, many don't see fintech as a significant threat to Canadian banks - and this has been a source of concern for those advocating for greater fintech growth and banking competition in Canada (Carmichael 2018). Further, Canada has been criticized for being "woefully unprepared" for the fintech-innovation wave that is happening (King 2018). Currently, fintech is not a wide 
threat to Canadian banking incumbents, but the major banks are launching their own research and development into fintech projects, including in "(b)lockchain technology, big data, automated advice and payments services" (Chan 2017). Also, Canadian banks are increasingly looking to partner or acquire fintech firms (Zochodne 2018). The recent entrance into the Canadian banking sector of new charters, who are focused on building market share by pursuing under-banked customers and using innovations in the digital space show that the incumbent big banks cannot become complacent in their products or service offerings (Ligaya 2017).

\section{CRYPTOCURRENCY AND INITIAL COIN OFFERINGS}

\section{CRYPTOCURRENCY: DEFINITIONAL IMPLICATIONS AND CHALLENGES}

The terms blockchain, Bitcoin and cryptocurrency have become common in the financial press; however, many people don't understand what they are, or the purpose they serve. One definition of blockchain is a "digitized, decentralized, public ledger" comprised of various distributed "nodes" or networked computers (Investopedia 2019). Private (permissioned) blockchains are also used as enterprise solutions (O'Connell 2016). Blocks on the blockchain are recent transactions (verified or "mined," time-stamped and authenticated through cryptography and linked to the previous block) and added in chronological order, which, once proven, are provided to each node as an "indelible" (permanent) digital transaction record (O'Connell 2016). Miners are provided with a cryptocurrency as a reward (Goodman and Partridge 2018, 2). Benefits of using a blockchain include no central authority (since trust in a transaction is ensured through cryptography and not a third party), an encrypted, secured ledger, transparency, faster and more efficient transactions and settlements, "user controlled" networks, and reduced transaction costs. However, concerns such as return on investment and energyconsumption costs exist (Williams 2017). There are also lingering uncertainties about transaction-settlement speed (Marr 2018).

The first major implementation of blockchain was Bitcoin (Kharpal 2018). Bitcoin was conceived in the release of an anonymous white paper in 2008, from a mysterious "Satoshi Nakamoto" (whose actual identity has yet to be determined), as a decentralized "peer-to-peer version of electronic cash" or "cryptocurrency," which allows for payments to be made between parties outside of banking intermediaries or governments (Nakamoto 2008). Bitcoin and other cryptocurrencies solve the "double spend" problem using a blockchain (rather than a central authority) and any transaction, once proven through cryptography, is broadcast to the entire network as part of an indelible record (Cointelegraph 2018). Bitcoin experienced a wild price run (and fall) from late 2017 to early 2018 due to, among other factors, increased speculation, general technological curiosity, its use as a digital hedge for unstable currencies, and demand from the ICO market (Clements 2018). Since its inception, Bitcoin has also been used extensively in conjunction with criminal enterprise, money laundering, hacking and cyber-fraud. It has been recently reported, however, that legal use is now exceeding criminal usage (Kuskowski 2018). 
Another popular cryptocurrency is Ethereum, a concept that envisions a decentralized internet (Kuskowski 2018). The Ethereum network is like a decentralized "world computer" (proprietary servers are replaced by volunteer nodes on the network) and applications on the network are powered by miners (volunteers who solve the cryptographic puzzles on the Ethereum blockchain) who are rewarded with the cryptocurrency Ether, which can be used as payment for applications, or exist as a standalone digital fiat (Kuskowski 2018). With Ethereum, you can use applications without third-party hosting or fees (Kuskowski 2018). Other popular cryptocurrencies include Bitcoin Cash (created by effectively a share split of Bitcoin, that has faster processing speeds to facilitate smaller payments), Litecoin (a competitor to Bitcoin as a form of digital money), and Ripple, a cryptocurrency that's used for interbank transfers (Reynard 2018).

Digital cryptocurrency faces significant hurdles in replacing conventional governmentbacked currency. On the practical side, at least currently, there are high transaction costs, fees and delays in using Bitcoin as payment (as opposed to nearly none with cash) and many vendors simply won't accept it given its volatility (Brown 2017). Bitcoin has a limited number of "coins" (21 million, once all coins are mined by 2140) and because of the high energy costs of maintaining the network, it may not be profitable for miners to keep the network going (Elnaj 2018). There are recurring questions about Bitcoin's ability to fulfill the threefold purpose of money, particularly in storing value (volatility) and serving as a medium of exchange (lack of vendor acceptance) (Elnaj 2018). Nevertheless, some people living under unstable government regimes consider it as a gold-like hedge against their own domestic currency volatility (Linuma 2018). Also, as recently noted in a speech by Bank of Canada Deputy Governor Timothy Lane (2018), the "pre-programmed monetary policy mechanism" of a defined supply of Bitcoin (thus eliminating the need for central authority) may actually have been a "fundamental flaw" in its price stability (and use as a currency substitute), since the limited supply was not able to keep up with large demand in late 2017.

As it currently stands, global regulators are quickly adapting to the reality of Bitcoin as a currency substitute (Rooney 2018). In the U.S., the Financial Crimes Enforcement Network (FinCEN, a department of the U.S. Treasury) has stated on its website (March 18, 2013) that virtual currency, although acting as a currency substitute, is not legal tender. This ruling is consistent with the approach in Canada where the federal government has noted on its website (2019) that only the Canadian dollar is legal tender. Another challenge in regulating cryptocurrency is that its legal definition has been interpreted in multiple ways, leading to regulatory uncertainty (and confusion). The CFTC (2018), the U.S. District Court for the Eastern District of New York (Meyer 2018), and most recently the U.S. District Court or Massachusetts (Marinoff 2018), have stated that cryptocurrencies, including Bitcoin, are commodities. The SEC, in its DAO ruling (2017), found that cryptocurrencies can (sometimes) be securities (Roberts 2017). The U.S. Internal Revenue Service (2014) has interpreted cryptocurrency in Notice 201421 as property for the purposes of tax assessment and as a result they are subject to reportable capital gains and losses, even when used as a payment mechanism. 


\section{CRYPTOCURRENCY EXCHANGES, FUNDS AND MANAGED PRODUCTS}

Bitcoin's wild price run in 2017 caused the public and regulators to take notice of cryptocurrency (Verhage 2017). Cryptocurrency exchanges can be (and often are) a frustrating mix of price volatility, trading-price discrepancies, uncertainty, and delays. These venues are also rife with allegations of price manipulation and serving as a haven for criminal enterprise. Such allegations are now empirically supported by research identifying the use of the digital currency Tether on the Bitfinex exchange to manipulate Bitcoin prices during the 2017 price run (Griffin and Shams 2018). Also, recent reports point to widespread fraud and "fake trading volume" in unregulated exchanges throughout the world (Vigna 2019).

Regulation that enables standardized, transparent and safe crypto-asset-trading venues is critical (Bambrough 2018). A recent Financial Action Task Force report gives some hope for enhanced exchange standards (Wada 2018). This is especially important given the recent report published by the New York Attorney General's Office (2018) noting a strong risk of manipulation on unsupervised cryptocurrency exchanges, and the lack of safeguards, and market surveillance and enforcement capabilities consistent with those of traditional securities exchanges. Unfortunately, many venues are operating without oversight, failing to properly register in the U.S. as a regulated national securities exchange or alternate trading system, or in Canada as a marketplace (Goodman and Partridge 2018, 7) or self-report (Rooney 2018). Also, some cryptocurrency platforms may offer services related to an exchange (such as a digital wallet with sales capabilities) and thus may trigger other regulatory obligations relating to dealer functions, brokerage, money transmission or clearing (Schroeder 2018).

In the U.S., given their various functions, cryptocurrency exchanges could be subject to oversight by FinCEN for being exchanges involved in money transmission (and subject to regulations regarding terrorist financing, money laundering and financial crime). They could be subject to oversight by the SEC, since some coin offerings are securities offerings. They could be subject to oversight by the CFTC, since this agency considers cryptocurrencies to be commodities. They could be subject to oversight by the Financial Industry Regulatory Authority (FINRA) with respect to marketing activities on a state basis in relation to money-transmission rules, consumer-protection legislation, antimoney-laundering and various other requirements. And, if they operate in New York, they could be subject to oversight by the Department of Financial Services "Bitlicense" regime (Myers Wood 2018). In 2017 the National Conference of Commissioners on Uniform State Law (also known as the Uniform Law Commission) released a Uniform Regulation of Virtual Currency Businesses Act, but it has yet to be enacted on an individual state level (Thompson Coburn 2018).

In Canada, the regulatory status of cryptocurrency exchanges is a live public-policy issue due to the recent failure of QuadrigaCX and its $\$ 190$ million in lost cryptocurrency (Copeland 2019). QuadrigaCX's insolvency resulted in a consultation paper (CP 21-402) being issued by the CSA (2019) on a proposed regulatory framework for crypto-asset trading platforms. The ultimate structure of this regulatory regime is uncertain, as is the ability of securities regulators to even assert jurisdiction over spot trading in certain crypto-assets, such as Bitcoin or Ether, that are widely distributed yet not considered 
to be securities. A cryptocurrency company or exchange may also be subject to a myriad of additional rules, including oversight by the Financial Transactions and Reports Analysis Centre of Canada (FINTRAC) with respect to fraud, terrorist financing and money laundering and by the Department of Justice, as well as being subject to various consumer and money-transmission regulations (Goodman and Partridge 2018, 11-13).

Another timely concern is the managed and exchange-traded-fund (ETF) sector. With respect to ETFs, the SEC rejected an application (originally filed in 2016, but rejected by the SEC on appeal) by Bats Exchange to list shares of the Winklevoss Bitcoin Trust and has delayed its decision on the VanEck SolidX Bitcoin Trust (Alexandre 2018). In 2018, the SEC also rejected several ETF applications citing price volatility and concerns about the potential for fraud and manipulation in the Bitcoin futures market and underlying spot markets; the rejections are currently under review (Chang 2018). The SEC isn't unanimous in its disapproval of a Bitcoin ETF. SEC Commissioner Hester Peirce (who dissented on the Winklevoss Bitcoin Trust) has criticized the decision, a move that has earned her the nickname "crypto mom" by Bitcoin enthusiasts online (Peirce 2018). The SEC also recently halted trading on two cryptocurrency products - Bitcoin Tracker One and Ether Tracker One, which were marketed as both ETFs and exchange-traded notes - citing "market confusion" (Hunnicutt 2018). Despite the SEC's reluctance to bless cryptocurrency ETFs, there are many actively managed cryptocurrency hedge funds in the U.S., offering investors a variety of exposure (Russo 2018).

A recent report estimated that nearly 100 new crypto-hedge funds were opened in the U.S. in 2018, down from over 150 in 2017 (Cryptofund Research 2018). These funds are attracting major institutional capital, including a recent investment from Yale University (Marsh and Katz 2018). The SEC has, however, been active in its enforcement actions for crypto-hedge funds that violate securities laws, including launching several cease-anddesist orders and fines (Rooney 2018). Underscoring these kinds of concerns, a "Bitcoin Investment Trust” (the Grayscale Bitcoin Investment Trust) recently lost over 80 per cent of its value since December 2017 and has been criticized for its steep fee structure (Bambrough 2018).

Canada also has actively managed cryptocurrency funds to supplement a healthy and growing blockchain ETF market (Sakovich 2018). A Bitcoin ETF (the Evolve Bitcoin ETF) has been filed but is awaiting regulatory approval (McGlone 2018). The Rivemont Crypto Fund, a mutual fund, launched in December 2017 and is restricted to only investing in six cryptocurrencies: Bitcoin, Ethereum, Litecoin, Ripple, Bitcoin Cash and Ethereum Classic (Owram 2018). First Block Capital also has a Bitcoin fund (the FBC Bitcoin Trust) that is only available to accredited investors ("Canada's First" 2018). First Block was granted, in September 2017, registration by the B.C. Securities Commission as an investment fund manager and exempt market dealer, the first such registration for a fund dedicated only to cryptocurrency (BCSC 2017).

\section{REGULATING CRYPTOCURRENCY DERIVATIVES}

In the summer of 2017, the CFTC granted registration to New York-based LedgerX as a derivatives-clearing organization and swap-execution facility to provide clearing services for Bitcoin options (puts and calls) and for fully collateralized day-ahead swaps. Further, 
in late 2017, Bitcoin futures started trading on the Chicago Mercantile Exchange and the CBOE Futures Exchange, and Bitcoin binary options began trading on the Cantor Exchange, under the exchange's "self-certification" process where the derivatives contracts were deemed to meet the exchange's internal risk-oversight requirements (CFTC 2017). The CFTC (2018) also recently released guidance to clearinghouses and exchanges planning on listing cryptocurrency derivatives through a joint advisory from the agency's Division of Market Oversight and Division of Clearing and Risk to aid exchanges to "design risk management programs that address the new risks" imposed by virtual-currency products and also ensure "appropriate governance processes." This guidance is especially relevant in light of the expanding derivatives-listing horizon that is likely to also shortly include options on Ether (CCN 2018) and plans from major Wall Street institutions for cryptocurrency-derivative products, including Morgan Stanley for Bitcoin swap trading and Goldman Sachs for Bitcoin non-deliverable forward contracts (Franck 2018).

In Canada, regulators have taken a guidance-based, cautious approach. Statements by the CSA (2017) identified "inherent risks associated with cryptocurrency futures" due to their trading on largely unregulated cryptocurrency venues. Also, the Canadian investment industry's self-regulatory organization, the Investment Industry Regulatory Organization of Canada (IIROC), in late 2017, pursuant to Rule Notice 17-0238, established "minimum margin requirements for cryptocurrency futures contracts." Also, pursuant to Multilateral Instrument 91-102 (which has been adopted widely by provincial securities regulators), binary options with a "term to maturity of less than 30 days with or to an individual, or to a person or company that was created or is used solely to trade a binary option" are prohibited (Borden Ladner Gervais 2016). A binary option is a "derivative product with a fixed (or maximum) payout if the option expires in the money, or the trader loses the amount they invested in the option if the option expires out of the money" (Chen 2018). Binary options are relevant in a cryptocurrency context because, in the U.S., the Cantor Exchange, in December 2017, self-certified a Bitcoin binary-option product (CFTC 2017). Therefore, Multilateral Instrument 91-102 provides an example of a regulatory distinction between Canada and the U.S. with respect to the permissive treatment by the latter of a wider variety of cryptocurrency options.

\section{REGULATING INITIAL COIN OFFERINGS (ICOS)}

In an ICO, a technology company raises money either "pre-release," to fund a project, or "post-release," to raise new funds for an ongoing project (McCann 2017), by selling its own cryptocurrency called "tokens" (Dudgeon and Malna 2018, 6-7). These are often used on the application or website that the company is creating (Popper 2017). In addition to use-based tokens, ICOs may also issue private cryptocurrencies (such as Bitcoin), create tokens with an ownership interest in a specific asset, such as real estate, or represent an ownership interest such as a security (Dale 2018). Filecoin, which describes itself on its website as a "decentralized storage network," raised US $\$ 257$ million in an ICO during August-September 2017 (Higgins 2017). Often in an ICO, purchasers will buy the tokens by exchanging a popular cryptocurrency (such as Bitcoin or Ether) for the new token (Popper 2018). 
Where ICOs have attracted regulatory attention is when the token that is being offered seems like more than just a "utility," and it starts to resemble an investment contract or security (CSA Staff Notice 46-308 2018). The use of the term "utility" in the context of an ICO is commonly associated with a type of offering that provides a specific useright to a product or service of the issuer. This can be contrasted with a "security" token, which provides a holder "a bundle of rights to govern the corporation, along with residual claims on its assets proportional to the number of shares they own" (Cohney et al. forthcoming, 8). If an ICO is an offering of securities then it will be subject to a wide host of securities registration, disclosure (initial and continuous), and resale restrictions pursuant to its offering jurisdiction and where investors are based (CSA Staff Notice 46307 2017). An error in judgement on the type of token that is being offered can be very costly for issuers, as evidenced by Operation Cryptosweep, a co-ordinated cross-border regulatory effort to crack down on illegal ICO offerings (NASAA 2018).

Perhaps the most important ruling in the regulatory evolution of ICOs in the U.S. was the SEC's (2017) investigative report of the DAO offering, which deemed an offering of profit-participation tokens to be an "investment contract" and subject to federal securities regulation. The SEC's ruling left unanswered the security status of tokens with a standalone utility. It is an important ruling when considering cryptocurrency offerings that will be subject to U.S. securities laws. In arriving at its conclusion on the DAO, the SEC applied the test for securities determination from Howey (1946), as well as other jurisprudence (Edwards 2004; United Housing Fund 1975; Tcherepnin 1967) to determine that the DAO tokens were "an investment of money in a common enterprise with a reasonable expectation of profits derived from the entrepreneurial or managerial efforts of others" and thus subject to securities laws (Howey 1946).

Shortly after the DAO ruling, the CSA advised that crypto-token offerings resembling the DAO offering were "likely" to be securities in Canada and subject to regulatory oversight (Roberts 2017). The Ontario Securities Commission (2017) also released an advisory note for companies utilizing distributed ledger technology on potential securities implications, and the British Columbia Securities Commission (2018) released BC Notice 2018/1 "Notice and Request for Comment - Consulting on the Securities Law framework for Fintech." The CSA further issued CSA Staff Notice 46-307 on Aug. 24, 2017 relating to ICOs and identified risks in these offerings (including volatility, opacity, valuation, and custody) and noted that offered tokens are frequently traded on unregulated online exchanges. Staff Notice 46-307 applied the following guidance, based on the Supreme Court of Canada's decision in Pacific Coast Coin (1977), on whether an ICO would be an investment contract (and subject to securities regulation): "does the ICO/ITO involve: 1) an investment of money; 2) in a common enterprise; 3 ) with the expectation of profit; to come significantly from the efforts of others." (CSA Staff Notice 46-307 2017, 3)

In October 2017, TokenFunder Inc. (a platform facilitating venture funding for other technology startups and digital-currency companies) had its ICO approved by the Ontario Securities Commission for distribution to retail investors (Stikeman Elliot 2018). Another notable Canadian ICO development was with Waterloo, Ont.-based Kik Interactive, which excluded Canadians from participation in its "Kin" token as a result of concerns that it would be deemed a security by the Ontario Securities Commission 
(Goodman and Partridge 2018, 5). A document called a "Simple Agreement For Future Token" (SAFT) has also been recently developed by cryptocurrency professionals to reduce ambiguity in this area (Goodman and Partridge 2017). This document works by "bifurcating the securities and token components of a transaction while preserving the many benefits associated with ICOs" and keeping the utility component (the "functional token" not as likely to be a security) separate from the security-like component (the "non-functional token") (Goodman and Partridge 2017). While more common in the U.S., the SAFT is not used much in Canada and each ICO must be analyzed for securities classification on its own (Goodman and Partridge 2017).

\section{FINTECH CREDIT AND MARKETPLACE LENDING}

\section{INTRODUCTION TO MARKET STRUCTURES AND BUSINESS MODELS}

Fintech credit (also called marketplace, online or peer-to-peer lending), like all fintech propositions, poses opportunity, such as more credit and enhanced deployment speed, and new risks, such as regulatory-supervisory difficulty (Lenz 2016). The business structures in peer-to-peer (P2P) lending vary, but as the Bank for International Settlements (BIS) $(2017,11)$ notes in its comprehensive report on fintech credit, they all generally revolve around a common theme: connecting borrowers with potential lenders through an online portal. Under a "traditional" P2P lending model, borrowers provide credit information to the platform, which undertakes risk analysis often using nontraditional credit-scoring metrics (Mavadiya 2018). The BIS report $(2017,11)$ identifies that lenders then choose which loans to fund and the loan contracting, disbursement of funds, and repayment takes place through the portal. Within the ambit of the traditional model is a "matching" variety where investors provide risk and duration parameters and are only shown potential loans that meet these criteria. Lenders often fund multiple loans to diversify risk, called "auto-select" loans (BIS 2017, 11-14). The terms of the loan (including prepayment penalties or privileges) will vary based on the investor and the platform (BIS 2017, 12).

The BIS report (2017, 11-16) also identifies a variety of business models for P2P lending, including a "notary model," which provides a matching service with the loan originating from a partnering bank (popular in Germany, South Korea and the U.S.) and the borrower provides credit data to the platform, which is shared with the investor and the partnering bank (which undertakes its own risk assessment). The model also facilitates securitization when loans are repackaged and sold to investors (BIS 2017, 12). Additional models noted in the report are a "guaranteed return" form, where the online platform promises a return of principle and/or interest to investors in exchange for a guarantee fee paid by the borrower (common in China); and a "balance sheet" model, where the online platform originates a loan (from retail or institutional investors) and the platform then holds the loan on its balance sheet, acting as a credit intermediary, a model often used in the U.K. to facilitate real estate loans (BIS 2017, 11-16). Also starting to appear are "invoice-trading models," where fintech firms offer factoring services (unsecured finance to manage cash flows) and there is potential for securitization through this model as well (BIS 2017, 16). 


\section{U.S. FINTECH-CREDIT REGULATORY OVERVIEW}

Fintech credit introduces new risks, including data breaches, operational risk, and moral hazard (BIS 2017, 11-16). This sector requires inter-agency jurisdictional co-ordination to effectively mitigate the risks inherent in new credit extension while ensuring the benefits that this new credit could bring to households, businesses and the economy (Saul and Curie 2018, 15). The U.S. Treasury report (2018, 11-12) recommended removing industry-growth barriers and codifying, by law, the "valid when made" doctrine, which would ensure banks are the "true lender" of loans they make (necessary in light of recent jurisprudence for banks that partner with fintech firms and transfer loans to them (Lo 2016)). The Treasury report (2018, 11-12) also recommends: ensuring mortgagelending rules are adapted to facilitate the extension of credit by non-bank financial firms; enabling the greater testing of fintech "new credit models and data" to facilitate wider credit access; and that "both federal and state banking regulators take steps to encourage prudent and sustainable short-term small-dollar instalment lending by banks." An example is rescinding the CFPB's "payday" rule" that applies to fintech shortterm, small-amount lenders. Also, the CFPB has shown a willingness through its Project Catalyst initiative, and the use of no-action letters to work with fintech lenders to ensure fair access to credit and non-discriminatory lending practices (Bruckner 2018, 58-59).

\section{CANADIAN FINTECH-CREDIT REGULATORY OVERVIEW}

The appetite for marketplace lending and fintech credit in Canada is rising. Canadian securities regulators take the position that P2P loans can be securities and fintechcredit companies may be dealers with registration and disclosure implications, unless they can utilize a suitable exemption (Lalonde 2017). The first online, peer-to-peer lending platform in Canada was Lending Loop. Lending Loop launched in 2015 and as of spring 2018 had funded over $\$ 20$ million worth of loans from more than 20,000 Canadian investors (Asano and King, 2018). Recently, the Ontario government proposed a \$3-million contribution, over two years, to loans originating through Lending Loop (Asano and King 2018). Nevertheless, there are calls for Canadian regulators to do more. Recent research on the Canadian loan market for small and medium-sized enterprises (SMEs) has noted a funding "gap" that could be filled by new, non-bank, fintech-credit companies (Hinton et al. 2017). Others have called on Canadian regulators to establish new marketplace lending regulations (as opposed to "shoehorning this sector under existing equity regulation"); raise retail limits for online lending; partner with industry to "provide more education for investors and small businesses"; and adopt a "mandatory referral program" (like that in the U.K.) where banks who reject credit applicants must refer potential borrowers to "alternative lenders" (Asano and King 2018).

The Competition Bureau (2017, 6, 47-48) suggests that Canadians might distrust nonbank fintech-lending platforms and this could serve as a deterrent for non-bank entrant growth; also that a fragmented regulatory structure governing new, non-bank, fintechcredit firms that aren't subject to OSFI oversight can be a significant cost and entry barrier for new firms. Potential regulatory oversight includes "money-services businesses" rules, securities jurisdiction and FINTRAC obligations (Stikeman Elliot 2018). For example, a fintech-credit company in Canada could be in the "business of trading" and subject to "dealer registration and platform-related recognition requirements" (albeit with suitable exemptions) under various provincial securities acts (Stikeman Elliot 2018). 


\section{FINTECH PAYMENTS, ROBO-ADVISERS AND FINANCIAL- ACCOUNT AGGREGATORS}

\section{REGULATING FINTECH-PAYMENTS INNOVATIONS}

The fintech-payments sector has a variety of potential consumer and business-tobusiness applications directed at widening the scope and enhancing the speed of available money-transfer and payment options (Bradbury 2017). A global example of fintech-payments success is M-Pesa, a phone-based money-transfer system growing rapidly in Africa. This sector is prime for bank partnerships, since tech firms can supply the technology and banks have customers and risk-management safeguards (Bradbury 2017). Payments innovations may also potentially reduce income inequality, as "realtime payments" could dramatically reduce the fees (estimated in the U.S. in the billions) that many low-income individuals face when relying on cheque-cashing services, payday lenders and bank overdraft services (Klein 2019). At the heart of the payment revolution is a desire to enhance the delivery speed, efficiency, convenience and diversity of available currencies, while reducing the cost of international and domestic financial transfers (Roser and Kang 2016, 651). Blockchain-payment innovations also provide value when local individuals or merchants stop trusting intermediaries ("Panel on Fintech" 2018). One prominent fintech-payments company is Ripple, which promised on its website on Feb. 25, 2019 a "frictionless experience to send money globally using the power of blockchain." Others include Venmo, as well as Zelle, an application owned by a group of large U.S. banks (Perez 2018). A Canadian-based startup, Finn.ai, has collaborated with both ATB Financial and BMO to facilitate payments from bank accounts from Facebook Messenger, and TD Bank has partnered with Kasisto to integrate artificialintelligence chat into its mobile application (Ligaya 2018).

The payments sector in the U.S. is both "operationally complex" and regulatorily "fragmented" and new firms must navigate a large host of "bank agencies' third-party oversight guidance," "state money transmitter statutes" and potential "private payment network operating rules and contracts" as well as consumer protection rules from the CFPB and the Federal Trade Commission (U.S. Treasury Department 2018, 145). In May 2015, the Faster Payments Task Force was convened by the U.S. Federal Reserve to provide in-depth analysis on how payments could be improved without significant risks. The task-force project concluded in two phases. First, with a detailed report of its approach (FPTFa 2017), and then with recommendations including improvements to regulatory frameworks and technological infrastructure (FPTFb 2017). The U.S. Treasury report $(2018,13,147,156)$ also made numerous recommendations for enhancing payment systems within a risk-contained network, including regulatory clarity, "harmonizing money transmitter requirements for licensing and supervisory expectations," continuing with the approach of the Faster Payments Task Force, and setting new public goals and deadlines to improve payments with an emphasis on retail applications and accessibility for small community banks and credit unions.

In Canada, the minister of finance supervises Payments Canada, which notes on its website it "is responsible for Canada's essential payments systems," and the Bank of Canada "regulates clearing and settlement systems and controls systemic or payments 
system risk" (Goodman and Partridge 2018, 13). Both entities, along with several private interests, recently embarked on the collaborative Project Jasper to research how blockchain technology could be used to improve wholesale payments, and in May 2018, the project's third phase announced proof of concept for "instantaneous clearing and settlement of securities" using blockchain technology (Bank of Canada 2019). The Department of Finance, in July 2017, also released a consultation paper called "A New Retail Payments Oversight Framework" proposing a federal oversight structure for retail payments. The oversight framework defined a wide scope of "payment service providers" (PSPs), including credit card, online payments, and peer-to-peer money transferors, which would have register as a "designated federal retail payments regulator" and these PSPS would have to adhere to a host of funding-safeguard measures, operational and privacy standards and disclosure requirements, and also submit to dispute-resolution mechanisms with potential liability for unauthorized transactions (McCarthy Tetrault 2017).

In its 2018 budget, the federal government of Canada noted the importance of fast and safe retail payments systems, and committed to consultation with stakeholders, including the provinces and territories, as well as a review of the Canadian Payments Act (Canada 2018). An area of identified concern as a potential barrier to new fintech entrants is access to data, which is needed for new market entrants to test technology (Hinton et al. 2017, 5). In Canada, fintech-payment companies also need to comply with applicable FINTRAC requirements (as money-services businesses), criminal law rules, or other privacy and consumer protection standards that apply (Competition Bureau 2017, 48). Also, in 2014, the Anti-Money Laundering Act was amended for money-services businesses dealing in digital currencies, but the changes are not currently in force as regulations are pending (Stikeman Elliot 2018).

Nevertheless, as noted by the Competition Bureau (2017, 5), "a strong governance framework is needed to prevent incumbent members and early entrants from strategically developing rules that exclude others from entering this sector in the future." This concern is particularly relevant in retail payments, since most new market entrants are within an intranetwork or downstream payments ecosystem and payments innovators, such as electronic wallets or retail-payment or money-transfer applications, are "inserting themselves between the deposit taking institution and the payment making customer" (Competition Bureau 2017, 23-26, 31). Thus new market entrants, according to the Competition Bureau (2017, 31), rely on an incumbent's access to core payment infrastructure (such as the Automated Clearing Settlement System) to operate. However, an incumbent is competing for the same customers, so it has an incentive to refuse to service a new fintech-payments firm that requires access - and this dynamic is exacerbated by a large institution's regulatory "de-risking" activities (Competition Bureau 2017, 31). To encourage greater competition and innovation in payments, the Competition Bureau $(2017,40)$ recommends fostering more fintech and bank collaboration to provide core infrastructure access and regulatory approval to permit merchants to "make use of their ability to use discounts or other incentives to encourage adoption of alternative or lower-cost payment methods" and to foster "greater awareness of product and service options." 


\section{REGULATING ROBO-ADVISERS: ALGORITHMIC WEALTH MANAGEMENT}

Another fintech innovation challenging regulatory paradigms are algorithmic wealth management platforms, popularly called robo-advisers. These provide investment recommendations and portfolio-management services to clients using data obtained from detailed questionnaires, such as age, risk tolerance and financial goals (lannarone 2018). There are many potential benefits of robo-advisers, such as professional wealthmanagement advice for clients who, because of remote locations or a lack of net worth, are unable to obtain such services, and platforms operate in conjunction with human oversight and in hybrid models (Lightbourne 2017, 652-653). Robo-advisers present both "promise" and "pitfalls" (D'Acunto et al. 2018). Positively, their automatic functioning can enhance household savings and serve as an antidote to a potential "retirement savings crisis" (Edwards 2018). One recent study identified robo-advisers as enhancing performance and effectively rebalancing under-diversified investment portfolios, as well as remedying common investing behavioural biases and heuristics for all classes of investors (D'Acunto et al. 2018, 3). There are many other potential benefits of robo-adviser platforms, including lower fees, reduced conflicts of interest, increased transparency, and increased investment quality (Baker and Dellaert 2018, 713, 734-735).

There are, however, drawbacks to using them, such as less diversification for previously diversified investors after the imposition of a robo-advising "optimizer" platform (D'Acunto et al 2018, 3). Robo-advisers have fiduciary implications and there is uncertainty on the assignment of liability when an algorithm fails to adhere to a fiduciary standard (Lightbourne 2017, 678-79). There are also new risks, and regulatory challenges like matching algorithms to clients to ensure suitable product choices, managing cybersecurity threats, data-protection and -management concerns including access and data quality, and scale - if a wide section of the consumer market is affected by a similar error, this could have systemic implications (Baker and Dellaert 2018, 734-35, 737-39, 742-744). There is also uncertainty if robo-advisory platforms will ever fully supplant traditional investment advisers (Litz 2018).

Digital wealth management in the U.S. is subject to a variety of regulators and overlapping rules (U.S. Treasury Department 2018, 162). Potential supervisors include the SEC and state securities regulators, FINRA for investment recommendations, state insurance regulators for insurance services, federal retirement guidelines for financial planning, federal and state consumer protection laws, as well as a myriad of potential banking, accounting, Department of Labor (for fiduciary obligations), and tax rules. There are also potential industry self-regulatory and conflict-of-interest guidelines (U.S. Treasury Department 2018, 162-63). The U.S. Treasury report $(2018,164)$ also expressed concerns that regulatory fragmentation is costly to this sector, and it "discourages the provision of integrated investment advice for assets held in retirement and nonretirement accounts"; therefore it recommended a "primary regulator" structure (likely the SEC or a state securities regulator). Also, the SEC (2019) recently fined two automated robo-adviser platforms, Wealthfront and Hedgeable, for making false statements and providing "misleading advertising."

There are many robo-advisory platforms in Canada including Wealthsimple, WealthBar, Justwealth, and Nest Wealth (Aston 2018). A robo-adviser in Canada could be subject to a 
diverse range of provincial and federal regulations, including provincial securities oversight and harmonized guidance through the CSA, federal criminal law, anti-money-laundering and fraud rules, federal and provincial consumer-protection legislation and governance through the banking prudential regulator OSFI. There is also industry self-regulation from IIROC with respect to "suitability" and "know-your-client" recommendations, which can be difficult to obtain in the context of robo-advisers (Competition Bureau 2017, 7, 18-19). The CSA issued Staff Notice 31-342 "Guidance for Portfolio Managers Regarding Online Advice" in 2015 noting the application of securities laws to robo-advisers, including knowyour-client obligations and potential due diligence and portfolio composition reviews by CSA staff for online platforms (Stikeman Elliot 2018). The staff notice makes the regulation of online advisers in Canada more "strenuous" than in the U.S., implying that traditional wealth management will still be in the picture for a while, with robo-adviser technology providing support-like tools in a "hybrid" model (McCarthy Tetrault 2018). Further, the CSA ensures that online advisers in Canada adhere to securities laws by requiring "custom terms and conditions," such as restrictions on margin, leverage or selling short (McCarthy Tetrault 2018). In addition, IIROC (2018) has issued Notice 18-0076, relating to "orderexecution only" (OEO) services by dealer members, generally prohibiting OEOs from providing investment recommendations, while providing guidance on how to adhere to OEO regulatory requirements.

\section{REGULATING FINANCIAL-ACCOUNT AGGREGATORS}

A final fintech innovation with significant disruptive potential is financial-account aggregators ("FAA"). FAAs operate in an "open-banking" paradigm with shared customer data among banks, centrally accessible by customers through a technology platform (called an "application programming interface" or API) that usually runs on a smartphone, and this framework could lower the costs and improve the efficiency of retail banking services, such as transferring funds between banks and comparing competing products (Investopedia 2018). The risks of aggregators are similar to other fintech risks: cyber-security, data breaches, financial fraud, and recovery (from unauthorized transactions). Financial-account aggregators are predicted to gain prominence in a "post-open-banking environment" where they will "sit on top of financial account data feeds and provide a place where customers can suck in all their data from the different financial institutions they deal with," yet the ability to achieve this result is largely contingent on new advancements in artificial intelligence (Crosman 2018). In the U.S., FINRA has identified consumer risks of potential data breaches because of account aggregators (Crosman 2018). In Canada, the 2018 federal budget included a specific undertaking to "review the merits of open banking in order to assess whether open banking would deliver positive results for Canadians with the highest regards for consumer privacy, data security and financial stability."

\section{CONCLUSION AND EMERGING ISSUES}

This article will conclude by identifying some of the key areas where continuing research is warranted. Despite its initial hype, large-scale blockchain implementation is not widespread (Ross 2017). Several blockchain projects are moving their way through proof 
of concept, but return on investment, interoperability, and operational functionality continue to be concerns (Crosman 2018). The U.S. swap-data repository Depository Trust and Clearing Organization (DTCC), blockchain developer Axoni, financial-servicessoftware firm R3 and IBM announced in early 2017 a blockchain-for-trade settlement and back-end processing for certain types of credit derivatives (Lielacher 2017). There are also projects contemplating blockchain in syndicated loans (Irrera 2017), securities trading (Hansen 2018) agricultural commodities and private equity deals (Crosman 2018); and, as previously noted, payments (Project Jasper through Payments Canada and the Bank of Canada).

Meanwhile, a project between DTCC and BNP Paribas SA relating to repo netting has been shelved due to uncertain cost and investment returns (Irrera and McCrank 2018). As blockchain technology, and smart contracts improve language interoperability (the extent that different blockchain networks can interact with each other through standardized coding languages, protocols and processes (Brown 2018)) and become more mainstream, there are also regulatory uncertainties such as the legal status (for the purposes of taxation) of "decentralized autonomous organizations" or entities that exist on a blockchain (Shakow 2018). Also unknown is the extent that blockchain applications will introduce new systemic risks into the financial system (Surujnath 2017).

As fintechs disrupt traditional banking and financial services, there are increasing calls for prudential and market-conduct supervisors to integrate technology, machine learning and complex algorithms to facilitate "real-time" regulatory oversight - a development commonly referred to as regulatory technology or "regtech" (Arner, Barberis and Buckley 2017, 371). As technology improves, it is increasingly difficult to know when to intervene, especially since errors in regulatory judgment (such as not having enough facts or data before establishing new rules) can stifle positive innovation and open up new problems (Fenwick, Kaal and Vermeulen, 2017). The challenge in using regtech is establishing an appropriate baseline for real-time supervision while enabling operational freedom (Baxter 2016, 603-604). However, regtech assumes that the digital oversight will be effective in its application and that additional government oversight will be minimal (Van Loo 2017, 1267).

Regulators are engaging in international regulatory data-sharing and collaboration agreements to avoid a "race to the bottom" (Lagarde 2018, 9). Fintech studies undertaken by the global-financial-standards Financial Action Task Force and the G2Ooriginated Financial Stability Board are positive steps in this regard (Lagarde 2018, 10). In August 2018, 11 global regulators and a World Bank Consultative Group proposed the Global Financial Innovation Network, which would serve as an international regulatory sandbox for multi-jurisdictional real-time product testing under supervisory review. In the U.S. the CFTC has expressed a willingness to co-ordinate with international regulators (Berry 2018). A recent example is its recent collaboration agreement with the FCA (CFTC 2018). Canada has been active in this regard as well. Several Canadian securities regulators have entered into agreements for fintech regulatory co-operation with Australia, France, Abu Dhabi and the United Kingdom (Stikeman Elliot 2018).

Another very important issue worth monitoring is whether new self-regulatory organizations (SROs) will be effective in fintech, particularly with cryptocurrency 
firms and exchanges. This is timely given the recent launch of the Virtual Commodity Association, which was created by Tyler and Cameron Winklevoss, founders of the Gemini Trust Company (Vigna 2018). The main concern with a cryptocurrency SRO is that it can't ensure member compliance without either a legislative mandate, or a credible threat that expulsion is a costly proposition to be avoided (Clements 2018). For example, if expulsion for non-compliance or the refusal to pay levied fines results in a firm no longer being able to do business in the industry, then a non-legislative mandate can be feasible (Clements 2018). This factor has been called a "market power" theory of SRO effectiveness (Macey and Novograd 2012, 966). This is not currently the case in cryptoasset trading.

The role that fintech plays in the continued complexifying of financial-market operations, participants, intermediary functions, products, services and underlying technology should be further studied (Schwarcz 2009, 213). Professor Dan Awrey (2012, 241) has described innovation a "process of change" - not necessarily one that implies improvement. As financial markets continue to complexify, regulators must be continually mindful of iatrogenic responses if poorly constructed laws are enacted that drive further system complexity and unintended effects. There are also uncertainties on the wider social impacts of fintech, including its impact on marginalized classes and income inequality problems (Bartlett et al. 2017; World Bank Group 2018). Additionally, the future of cryptocurrency as a money substitute is uncertain, as well as its net environmental impact. Also, no one knows the extent to which it will integrate into shadow-banking and wholesale-funding markets, its continuing impact on monetary policy, and the likelihood that central banks will inevitability utilize their own blockchain-based digital currency (Lane 2018).

Finally, principles-based frameworks (and sandboxes) are not a panacea. Professor Steven Schwarcz (2009, 264-265) notes that, even though principles-based systems are commonly used for fast-changing systems, our ever-more complex and "internationalized" financial markets (spurred by fintech) makes it "increasingly harder for regulators and market participants to act together as a community" and this, in turn, makes principlesbased regimes not as effective. Also, as identified by SEC Commissioner Hester Peirce (2018), sandboxes may be slow to keep pace with innovation and thus, self-certification mechanisms may be worth exploring. Future studies should be undertaken on the externalities of principles-based regimes and sandboxes, including whether they introduce a greater propensity for regulatory bias, regulatory capture, or competition distortion. 


\section{REFERENCES}

Alberta Securities Commission. 2018. Press Release, "Alberta Securities Commission Establishes New Economy Division and Appoints Directors," June 25, 2018. Available from https://www.albertasecurities.com/News-and-Publications/NewsReleases/2018/10/Alberta-Securities-Commission-establishes-New-Economydivision-and-appoints-Director.

Alexandre, Ana. 2018. "US SEC Postpones Decision Regarding Bitcoin Exchange Traded Fund," Coin Telegraph, August 8, 2018, https://cointelegraph.com/news/us-secpostpones-decision-regarding-bitcoin-exchange-traded-fund.

Ancri, Clement. 2016. "Fintech Innovation: An Overview, Presentation of Board of Governors of the Federal Reserve System to the World Bank," Paper presented to the World Bank by the Federal Reserve Board of Governors, October 19, 2016. Available from pubdocs.worldbank.org/en/767751477065124612/11-Fintech.pdf.

Arner, Douglas W., Janos Barberis and Ross P. Buckley. 2017. "Fintech, Regtech, and the Reconceptualization of Financial Regulation," Northwestern Journal of International Law and Business 37: 371-414.

Arner, Douglas W., Janos Barberis, and Ross P. Buckley, 2016. "The Evolution Of Fintech: A New Post-Crisis Paradigm?” Georgetown Journal of International Law, 47 (2016): 1271-1319.

Asano, Craig and Michael King. 2018. "Peer-to-Peer Lending Will Help Small Businesses Stay Afloat," The Globe and Mail, May 30, 2018, https://www.theglobeandmail.com/ business/commentary/article-peer-to-peer-lending-will-help-small-businesses-stayafloat/.

Aston, David. 2018. "An Investors Guide To Robo-Advisors 2018," Money Sense, April 29, 2018, https://www.moneysense.ca/save/investing/an-investors-guide-to-roboadvisors-2018/.

Awrey, Dan. 2012. "Complexity, Innovation, and the Regulation of Modern Financial Markets," Harvard Business Law Review 2: 235-294.

Badour, Ana, Lynde, D.J. and Firestone, Jessica. 2017. "Partnerships Between Banks and Fintech Companies: A Continuing Trend for 2017," McCarthy Tetrault, February 22, 2017. Available from https://www.mccarthy.ca/en/insightsblogssnipits/partnershipsbetween-banks-and-fintech-companies-continuing-trend-2017.

Bailey, Christopher G. 2018. "Fintech’s Double Edges,” Chicago-Kent Law Review 93: 61-95.

Baker, Todd. 2018. "Why There's No Need For The OCC's Fintech Charter," American Banker, October 1, 2018, https://www.americanbanker.com/opinion/why-theres-noneed-for-the-occs-fintech-charter.

Baker, Tom and Benedict Dellaert. 2018. "Regulating Robo Advice Across the Finance Services Industry," lowa Law Review 103: 713-750.

Bambrough, Billy. 2018. "Blow To Bitcoin As U.S. Investment Trust Tanks," Forbes, October 3, 2018, https://www.forbes.com/sites/billybambrough/2018/10/03/blowto-bitcoin-as-u-s-investment-trust-tanks/\#51e5d1a71b89. 
Bambrough, Billy. 2018. "IMF Issues Stark Warning Over Bitcoin and Crypto 'Rapid' Growth,” Forbes, October 9, 2018, https://www.forbes.com/sites/ billybambrough/2018/10/09/imf-issues-stark-warning-over-bitcoin-and-cryptorapid-growth/\#4cf7cb383544.

Bank of Canada. 2019. "Fintech Experiments and Projects," accessed March 2, 2019, https://www.bankofcanada.ca/research/digital-currencies-and-fintech/fintechexperiments-and-projects/.

Bank for International Settlements, Fintech Credit: Market Structures, Business Models and Financial Stability Implications, Report Prepared By A Working Group Established By The Committee on The Global Financial System (CGFS) and the Financial Stability Board (FSB), 11 (22 May 2017). Available from http://www.fsb.org/ wp-content/uploads/CGFS-FSB-Report-on-FinTech-Credit.pdf.

Barefoot, Jo Ann S. 2016. "Regulatory Innovation," Fintech Law Report 19, no. 3: 1-9.

Bartlett, Robert P., Adair Morse, Richard H. Stanton, and Nancy E. Wallace. 2017.

"Consumer Lending Discrimination in the FinTech Era," UC Berkeley Public Law Research Paper, December 7, 2017. Available from https://papers.ssrn.com/sol3/ papers.cfm?abstract_id=3063448.

Basel Committee on Banking Supervision. 2018. Sound Practices, Implications of Fintech Developments For Banks and Bank Supervisors, February 2018. Available from https://www.bis.org/bcbs/publ/d431.pdf.

Baxter, Lawrence G. 2016. "Adaptive Financial Regulation and RegTech: A Concept Article On Realistic Protection For Victims Of Bank Failures,” Duke Law Journal 66: 567-604.

Berry, Kate. 2018. "CFPB to collaborate on fintech issues with foreign regulators," American Banker, August 7, 2018, https://www.americanbanker.com/news/cfpb-tocollaborate-on-fintech-issues-with-foreign-regulators.

Borden Ladner Gervais. 2016. "Regulating Fintech in Canada: Financial Services Regulatory Bulletin,” updated October 28, 2016. Available from https://blg.com/en/ News-And-Publications/Publication_4717.

Bradbury, Danny. 2017. "How fintech companies are tackling payments - and who's helping," Financial Post, September 11, 2017, https://business.financialpost.com/ entrepreneur/money/how-fintech-companies-are-tackling-payments-and-whoshelping.

British Columbia Securities Commission. 2018. "BCSC Consults With Stakeholders in Financial Technology Sector" February 14, 2018. Available from https://www.bcsc. bc.ca/News/News_Releases/2018/11_BCSC_consults_with_stakeholders_in_ financial_technology_sector/.

British Columbia Securities Commission. 2017. "B.C. Securities Commission Grants Landmark Bitcoin Investment Fund Manager Registration” September 6, 2017. Available from https://www.bcsc.bc.ca/News/News_Releases/2017/69_B_C__ Securities_Commission_grants_landmark_bitcoin_investment_fund_manager_ registration/. 
Browne, Ryan. 2017. "Big Transaction Fees Are a Problem for Bitcoin - But There Could Be a Solution,” CNBC, December 19, 2017, https://www.cnbc.com/2017/12/19/bigtransactions-fees-are-a-problem-for-bitcoin.html.

Browne, Ryan. 2018. "Five things that must happen for blockchain to see widespread adoption, according to Deloitte," CNBC October 1, 2018, https://www.cnbc. com/2018/10/01/five-crucial-challenges-for-blockchain-to-overcome-deloitte.html.

Bruckner, Matthew Adam. 2018. "The Promise and Perils of Algorithmic Lenders' Use of Big Data," Chicago-Kent Law Review 93 no. 3: 1-60.

Brummer, Chris. 2015. "Disruptive Technology and Securities Regulation," Fordham Law Review 84: 977-1052.

Burns, Hilary. 2018. "Why This Fintech Pulled Its FDIC Charter Application," American Banker, September 27, 2018, https://www.americanbanker.com/news/why-thisfintech-pulled-its-fdic-charter-application.

Canada, "Budget 2018, Annex 3 - Strengthening and Modernizing Canada's Financial Sector," https://www.budget.gc.ca/2018/docs/plan/anx-O3-en.html\#Review-ofOpen-Banking.

Canada. Department of Finance, "A New Retail Payments Oversight Framework," accessed October 6, 2018, https://www.fin.gc.ca/activty/consult/rpof-cspd-eng.asp.

"Canada's First Bitcoin Fund Now Available on NEO Connect," Financial Post Business Wire, September 10, 2018, https://business.financialpost.com/pmn/press-releases$\mathrm{pmn} /$ business-wire-news-releases-pmn/canadas-first-bitcoin-fund-now-available-onneo-connect.

Canadian Securities Administrators. 2018. "Canadian Securities Administrators Remind Investors Of Inherent Risks Associated With Cryptocurrency Futures Contracts" December 18, 2017. Available from https://www.securities-administrators.ca/ aboutcsa. aspx?id=1641.

Canadian Securities Administrators. 2017. "Canadian Securities Regulators Outline Securities Requirements That May Apply To Cryptocurrency Offerings," August 24, 2017. Available from https://www.securities-administrators.ca/aboutcsa. aspx?id=1606.

Canadian Securities Administrators. 2018. "Canadian Securities Regulators Provide Additional Guidance on Securities Law Implications for Offerings of Tokens," June 11, 2018. Available from https://www.securities-administrators.ca/aboutcsa. aspx?id=1704.

Canadian Securities Administrators. 2019. "Canadian Securities Regulators Consult on Regulatory Framework For Crypto-Asset Trading Platforms” March 14, 2019. Available from https://www.securities-administrators.ca/aboutcsa.aspx?id=1776.

Canadian Securities Administrators. 2019. "CSA Regulatory Sandbox," https://www. securities-administrators.ca/industry_resources.aspx?id=1588. Accessed February 25, 2019. 
Carmichael, Kevin. 2018. "Canada Should Be A World-Beater in Fintech, but Isn't," Financial Post, May 7, 2018, https://business.financialpost.com/news/economy/ canada-should-be-a-world-beater-in-fintech-but-isnt.

CCN. 2018. "Cryptocurrency Derivatives Platform LedgerX Will Launch Ether Options: Report," accessed September 25, 2018, https://www.ccn.com/cryptocurrencyderivatives-platform-ledgerx-will-launch-ether-options-report/.

Chambers, Clem. 2018. "What's Next for The Price of Bitcoin?” Forbes, April 19, 2018, https://www.forbes.com/sites/investor/2018/04/19/whats-next-for-the-price-ofbitcoin/\#1338828449b2.

Chan, Helen. 2017. "Canadian Regulators Welcome Fintech Amid Increasing Global Oversight Interest," Reuters, February 24, 2017, https://www.reuters.com/article/ bc-finreg-canada-fintech/canadian-regulators-welcome-fintech-amid-rising-globaloversight-interest-idUSKBN1622A7.

Chang, Ellen. 2018. "Approval of Bitcoin ETFs by SEC Appears Murky," US News and World Report, October 9, 2018, https://money.usnews.com/investing/ cryptocurrency/articles/2018-10-09/approval-of-bitcoin-etfs-by-sec-appears-murky.

Chen, James. "Binary Option,” Investopedia, December 11, 2018, https://www. investopedia.com/terms/b/binary-option.asp.

Chiu, Iris H-Y. 2016. "Fintech and Disruptive Business Models in Financial Products, Intermediation and Markets - Policy Implications For Financial Regulators," Journal of Technology Law and Policy 21: 55-112

Clements, Ryan. 2018. "Assessing the Evolution of Cryptocurrency: Demand Factors, Latent Value and Regulatory Developments," Michigan Business and Entrepreneurial Law Review 8: 73-100.

Clements, Ryan. 2018. "Can a Cryptocurrency Self-Regulatory Organization Work? Assessing Its Promise and Likely Challenges," Duke Global Financial Markets Center FinReg Blog, June 21, 2018. Available from https://sites.duke.edu/ thefinregblog/2018/06/21/can-a-cryptocurrency-self-regulatory-organization-workassessing-its-promise-and-likely-challenges/.

Clozel, Lalita. 2017. "SoFi Withdraws Bank Application in Wake of Scandal," American Banker, October 13, 2017, https://www.americanbanker.com/news/sofi-withdrawsbank-application-in-wake-of-scandal.

Clozel, Lalita. 2018. “'Fintech Charter' Has No Early Takers as Lawsuit Looms,” The Wall Street Journal, September 12, 2018, https://www.wsj.com/articles/fintech-charterhas-no-early-takers-as-lawsuit-looms-1536764426.

CNBC. 2018. "5 Fintech Trends That Are Transforming Financial Services," accessed April 13, 2019, https://www.cnbc.com/advertorial/2018/06/01/5-fintech-trends-that-aretransforming-financial-services.html.

CNBC. 2017. "The Fintech Effect: Everything You've Always Wanted To Know About Fintech," accessed April 13, 2019, https://www.cnbc.com/2017/10/02/fintecheverything-youve-always-wanted-to-know-about-financial-technology.html. 
Cohney, Shaanan, David A. Hoffman, Jeremy Sklaroff and David Wishnick. 2018. "Coin-Operated Capitalism," forthcoming Columbia Law Review. University of Pennsylvania, Institute for Law and Economic Research Paper No. 18-37. Available from http://dx.doi.org/10.2139/ssrn.3215345.

Cointelegraph, "What Is Cryptocurrency. Guide For Beginners," accessed September 28, 2018, https://cointelegraph.com/bitcoin-for-beginners/what-arecryptocurrencies\#buy-goods.

Competition Bureau of Canada, 2017. Technology-Led Innovation In The Canadian Financial Services Sector - A Market Study, December 2017 (Ottawa: Competition Bureau of Canada, 2017), Available from http://www.competitionbureau.gc.ca/eic/ site/cb-bc.nsf/vwapj/FinTech-MarketStudy-December2017-Eng.pdf/\$FILE/FinTechMarketStudy-December2017-Eng.pdf.

Copeland, Tim. 2019. "The Complete Story of the QuadrigaCX $\$ 190$ Million Scandal," Decrypt, March 13, 2019, https://decryptmedia.com/5853/complete-storyquadrigacx-190-million.

Crosman, Penny. 2018. " 5 Ways The World Economic Forum Says Al is Changing Banking," American Banker, August 26, 2018, https://www.americanbanker.com/ list/5-ways-the-world-economic-forum-says-ai-is-changing-banking.

Crosman, Penny. 2018. "Is FINRA's dire warning about data aggregators on target?" American Banker, April 9, 2018, https://www.americanbanker.com/news/is-finrasdire-warning-about-data-aggregators-on-target.

Crosman, Penny. 2018. "The Reasons U.S. Blockchain Adoption has Stalled," American Banker, Mar. 23, 2018., https://www.americanbanker.com/news/the-reasons-usblockchain-adoption-has-stalled.

CryptoFund Research. "2018 Crypto Fund Launches," accessed April 19, 2019, https://cryptofundresearch.com/crypto-fund-launches-2018/.

CSA Staff Notice 46-307, Cryptocurrency Offerings (2017). Available from https://albertasecurities.com/securities-law-and-policy/regulatory-instruments/46-307.

CSA Staff Notice 46-308, Securities Law Implications for Offerings of Tokens (2018). Available from https://albertasecurities.com/securities-law-and-policy/regulatoryinstruments/46-308.

Curry, Thomas and Jason Cabral, "It's A Mistake To Block The OCC's Fintech Charter," American Banker, September 24, 2018, https://www.americanbanker.com/opinion/ its-a-mistake-to-block-the-occs-fintech-charter.

Cutts, Matthew D. and Roman, Brandon C. 2016. "The Future of FinTech: A Washington Perspective," Fintech Law Reporter NL. 19, no. 6: 1-11.

D’Acunto, Francesco, Nagpurnan Prabhala, and Alberto Rossi. 2018. "The Promises and Pitfalls of Robo-Advising," CESifo Working Paper Series No. 6907. Available from https://ssrn.com/abstract=3165339. 
Dale, Brady. 2018. "Real Estate ICOs are Moving In, But Investors Aren't Floored," Coindesk, February 13, 2018, https://www.coindesk.com/real-estate-icos-movinginvestors-arent-floored.

Deloitte LLP. 2016. Closing The Gap: Encouraging Fintech Innovation in Canada 2016, available from https://www2.deloitte.com/content/dam/Deloitte/ca/Documents/ financial-services/CA-2017-FSI-EN-Closing-the-gap-AODA.PDF.

Dentons LLP. 2017. “The Regulation of Fintech in Canada." Updated April 20, 2017. Available from https://www.dentons.com/en/insights/articles/2017/april/20/ regulation-of-fintech-in-canada.

Desai, Falguni. 2015. "The Evolution of Fintech,” Forbes, December 13, 2015, https://www. forbes.com/sites/falgunidesai/2015/12/13/the-evolution-of-fintech/\#19db10357175.

DMZ-BMO Fintech Accelerator, https://dmz.ryerson.ca/programs/fintech/. Accessed September 26, 2018.

Dolmetsch, Chris. 2018. "N.Y. Sues Comptroller Of Currency Over Fintech Charter Decision,” Bloomberg, September 14, 2018, https://www.bloomberg.com/news/ articles/2018-09-14/n-y-sues-comptroller-of-currency-over-fintech-charter-decision.

Douglas, John L. and Grinberg, Reuben. 2017. "Old Wine in New Bottles: Bank Investments In Fintech Companies," Review of Banking and Financial Law 36: 667-711.

Dudgeon, Nathan and Gareth Malna. 2018. "Distributed Ledger Technology: From Blockchain To ICOs," Banking and Financial Services Policy Review 37, no. 2:1-9.

Edwards, Benjamin P. 2018. "The Rise of Automated Investment Advice: Can RoboAdvisers Rescue The Retail Market?” Chicago-Kent Law Review 93: 97-111.

Elnaj, Saeed. 2018. "The Problems With Bitcoin and The Future of Blockchain," Forbes, March 29, 2018, https://www.forbes.com/sites/forbestechcouncil/2018/03/29/theproblems-with-bitcoin-and-the-future-of-blockchain/\#49cf883a68dc.

Faster Payments Task Force. 2017. "The U.S. Path to Faster Payments Final Report Part One: The Faster Payments Task Force Approach," January 2017. Available from https://fasterpaymentstaskforce.org/wp-content/uploads/faster-payments-finalreport-part1.pdf.

Faster Payments Task Force. 2017. "The U.S. Path to Faster Payments Final Report Part Two: A Call to Action,” July 2017. Available from https://fasterpaymentstaskforce. org/wp-content/uploads/faster-payments-task-force-final-report-part-two.pdf.

Fenwick, Mark, Wulf A. Kaal and Erik P.M. Vermeulen. 2017. "Regulation Tomorrow: What Happens When Technology Is Faster Than The Law?” American University Business Law Review 6: 561-594.

Ford, Christie. 2010. "Principles-Based Securities Regulation in the Wake of the Global Financial Crisis," McGill Law Journal 55, no.2: 257-307.

Financial Consumer Agency of Canada, “Digital Currency,” accessed September 28, 2018, https://www.canada.ca/en/financial-consumer-agency/services/payment/digitalcurrency.html\#toc1. 
FinExtra, 2018. "Arizona Opens First Fintech Sandbox In The US," accessed March 29, 2019, https://www.finextra.com/newsarticle/32489/arizona-opens-first-fintechsandbox-in-the-us.

Franck, Thomas. 2018. "Morgan Stanley Gearing Up For Bitcoin Derivative Trading, Bloomberg Reports," CNBC, September 13, 2018, https://www.cnbc. com/2018/09/13/morgan-stanley-gearing-up-for-bitcoin-derivative-trading.html.

Galea, Irene. 2018. "Canada's property market may be cooling, but 'proptech' is booming," Financial Post, December 27, 2018, https://business.financialpost.com/ real-estate/canadas-property-market-may-be-cooling-but-proptech-is-booming.

Gavin, Jeff, Feng Han, Sarah Hynes, John Qu, Kausik Rajgopal and Arthur Shek, "Synergy and Disruption: Ten Trends Shaping Fintech," McKinsey Report. Updated December 2018. Available from https://www.mckinsey.com/industries/financial-services/ourinsights/synergy-and-disruption-ten-trends-shaping-fintech.

Global Financial Innovation Network. 2018. “Consultation Document,” August 2018. Available from https://www.fca.org.uk/publication/consultation/gfin-consultationdocument.pdf.

Gilroy, Michael. 2017. "Fintech's Future Is in the Back-End," American Banker, May 10, 2017, https://www.americanbanker.com/opinion/fintechs-future-is-in-the-back-end.

Giovannetti, Justin. 2017. "Ontario to Ease Regulations on Financial Startups,” The Globe and Mail, November 13, 2017, https://www.theglobeandmail.com/news/national/ ontario-to-ease-regulations-on-financial-startups/article36873205/.

Goodman, Allan and Michael Partridge. 2018. "Cryptocurrency in Canada," Practical Law Canada Practice Note w-013-8891, (2018). Available from http://www.goodmans.ca/ files/file/docs/Cryptocurrency\%20in\%20Canada\%20published\%2005\%2022\%2018.pdf.

Goodman, Allan and Michael Partridge. 2017. "Read This Before Your ICO: Exploring The SAFT Framework For Compliant Token Sales In Canada," Goodmans LLP, December 6, 2017. Available from http://www.goodmans.ca/Doc/Read_this_Before_Your_ICO__ Exploring_the_SAFT_Framework_for_Compliant_Token_Sales_in_Canada.

Griffin, John M. and Amin Shams. 2018. "Is Bitcoin Really Un-Tethered?” unpublished manuscript. Available from https://ssrn.com/abstract=3195066.

Hannah, Darren. 2018. "Today's Tech Hype in Banking is Real, It's Not The Hyperbole of 2000," Canadian Banking Association, July 4, 2018, https://cba.ca/tech-hype-inbanking-is-real.

Hansen, Sarah. 2018. "DTCC Study: Tech Inspired By Bitcoin Could Work For U.S. Equity Markets," Forbes. October 16, 2018, https://www.forbes.com/sites/ sarahhansen/2018/10/16/dtcc-study-tech-inspired-by-bitcoin-could-work-for-usequity-markets/\#323aea2036do.

Hartmans, Avery. 2016. "Millennials' Distrust of Banks is Spawning A New Breed of Startups," Business Insider, August 14, 2016, https://www.businessinsider.com/ millennials-distrust-banks-new-startups. 
Higgins, Stan. 2017. “\$257 Million: Filecoin Breaks All-Time Record For ICO Funding,” Coin Desk, September 7, 2017, https://www.coindesk.com/257-million-filecoin-breakstime-record-ico-funding/.

Hinton, James W., Domenico Lombardi and Joanna Wajda. 2017. "Issues in Bringing Canadian Fintech to the International Stage," Centre For International Governance Innovation Policy Brief, 111 (2017). Available from https://www.cigionline.org/ publications/issues-bringing-canadian-fintech-international-stage.

Hunnicutt, Trevor. 2018. "SEC Halts Trading In Two Cryptocurrency Products, Citing Market Confusion,” Reuters, September 9, 2018, https://www.reuters.com/article/ususa-cryptocurrency-sec/sec-halts-trading-in-two-cryptocurrency-products-citingmarket-confusion-idUSKCN1LPOTW.

Iannarone, Nicole G. 2018. "Computer as Confidant: Digital Investment Advice and the Fiduciary Standard," Chicago-Kent Law Review 93: 141-163.

Investment Industry Regulatory Organization of Canada. 2017. "Margin Requirements For Cryptocurrency Futures Contracts," December 11, 2017. Available from http://www. iiroc.ca/documents/2017/77509C44-8E4B-45A1-8FFB-4FD478FD076D_en.pdf

Investment Industry Regulatory Organization of Canada. 2018. "IIOC Notice 18-0076," April 9, 2018. Available from http://www.iiroc.ca/Documents/2018/54DF3AAOO6D8-48FD-8E93-CE469BE1C650_en.pdf.

Internal Revenue Service, IRS Notice 2014-21, March 25, 2014. Available from https://www.irs.gov/pub/irs-drop/n-14-21.pdf.

Investopedia, "Blockchain," https://www.investopedia.com/terms/b/blockchain.asp, accessed February 25, 2019.

Investopedia, "Open Banking," https://www.investopedia.com/terms/o/open-banking.asp, accessed September 22, 2018.

Irrera, Anna. 2017. "DTCC to rebuild credit default swaps processing platform with blockchain," Reuters, January 9, 2017, https://www.reuters.com/article/usblockchain-dtcc-cds/dtcc-to-rebuild-credit-default-swaps-processing-platform-withblockchain-idUSKBN14T1EA.

Irrera, Anna and John McCrank. 2018. "Wall Street ReThinks Blockchain Project As Euphoria Meets Reality,” Reuters, March 27, 2018, https://www.reuters.com/article/ us-banks-fintech-blockchain/wall-street-rethinks-blockchain-projects-as-euphoriameets-reality-idUSKBN1H32GO.

Jackson, James K. 2013. "Financial Market Supervision: Canada's Perspective," Congressional Research Service, Report for Congress 7-5700, April 2013. Available from https://fas.org/sgp/crs/misc/R40687.pdf.

Kagan, Julia. 2019. "Fintech," Investopedia, accessed April 13, 2019, https://www.investopedia.com/terms/f/fintech.asp. 
Kearns, Wendy, Andrew J. Lorentz and Julia Dempewolf, "Fintech Sandboxes - Update On State Approaches," Payment Law Advisor, April 16, 2018. Available from https://www.paymentlawadvisor.com/2018/04/16/fintech-sandboxes-update-onstate-approaches/.

Kharpal, Arjun. 2018. "The Blockchain Revolution: Everything You Need To Know About The Blockchain,” CNBC, June 29, 2018, https://www.cnbc.com/2018/06/18/ blockchain-what-is-it-and-how-does-it-work.html.

Kidd, Jeremy. 2018. “Fintech: Antidote To Rent-Seeking?” Chicago-Kent Law Review 93: 165-192.

Kimbrell, Gideon. 2018. "Three Breakthroughs That Will Disrupt The Tech World In 2019," Forbes, July 18, 2018, https://www.forbes.com/sites/forbestechcouncil/2018/07/18/ three-breakthroughs-that-will-disrupt-the-tech-world-in-2019/\#20e02e21f873.

King, Michael R. 2018. "Canada is woefully unprepared for the fintech tsunami," Financial Post, February 4, 2018, https://business.financialpost.com/entrepreneur/canada-iswoefully-unprepared-for-the-fintech-tsunami.

Klein, Aaron, "The Fastest Way To Address Income Inequality? Implement A Real Time Payment System," Brookings Institute Report, January 2, 2019. Available from https://www.brookings.edu/research/the-fastest-way-to-address-income-inequalityimplement-a-real-time-payment-system/.

Knight, Brian. 2017. "Federalism and Federalization on the Fintech Frontier," Vanderbilt Journal of Entrepreneurial and Technology Law 20: 129-206.

Kuskowski, Pawel. "Crypto Isn't As Risky As It Used To Be, But Regulators Could Still Do More," Forbes, October 1, 2018, https://www.forbes.com/ sites/pawelkuskowski/2018/10/01/why-crypto-isnt-as-risky-as-it-used-tobe/\#3a74b80a27c1.

Lagarde, Christine. 2018. "A Regulatory Approach To Fintech" Finance and Development 55, no.2: 1-11.

Lalonde, Riley. 2017. "P2P Lending and How It's Regulated," EKB Fintech Blog, November 23, 2017, http://www.ekb.com/p2p-lending-and-how-its-regulated/.

Lane, Timothy. 2018. “Decrypting “Crypto,” Speech Given To Haskayne School of Business, University of Calgary, October 1, 2018, available at https://www.bankofcanada.ca/2018/10/decrypting-crypto/.

LaPlante, Alex and Charlotte Watson. 2018. "The Great Fintech Debate: Risks and Rewards of Financial Innovation," Global Risk Institute Financial Innovation Series Report. Updated May 8, 2018. Available from https://globalriskinstitute.org/ publications/risks-and-rewards-of-financial-innovation/.

Laplante, Alex and Charlotte Watson. 2018. "We've Got To Maximize Opportunities and Minimize Risks in Fintech," The Globe and Mail, May 28, 2018, https://www. theglobeandmail.com/business/commentary/article-weve-got-to-maximizeopportunities-and-minimize-risks-in-fintech/. 
Lenz, Rainer. 2016. "Peer-to-Peer Lending: Opportunities And Risks," European Journal of Risk Regulation 7: 688-700.

Lielacher, Alex. 2017. "DTCC to Launch Blockchain Credit Default Swaps Reporting in Early 2018," NASDAQ, May 25, 2017, http://www.nasdaq.com/article/dtcc-to-launchblockchain-credit-default-swaps-reporting-in-early-2018-cm794771.

Ligaya, Armina. 2018. "BMO Launches Al-Powered Chatbots on Facebook and Twitter," The Globe and Mail, March 15, 2018, https://www.theglobeandmail.com/reporton-business/bmo-launches-ai-powered-chatbots-on-facebook-and-twitter/ article38288966/.

Ligaya, Armina. 2017. "New banks try to carve out a niche the Big Six don't already dominate in hyper-profitable business," Financial Post, March 10, 2017, https://business.financialpost.com/news/fp-street/new-banks-try-to-carve-out-aniche-the-big-six-dont-already-dominate-in-hyper-profitable-business.

Lightbourne, John. 2017. "Algorithms and Fiduciaries: Existing and Proposed Regulatory Approaches to Artificially Intelligent Financial Planners," Duke Law Journal 67: 651-679.

Linuma, Arthur. 2018. "Bitcoin - A Long Way From An Everyday Currency: Expert Blog," Coin Telegraph, January 7, 2018, https://cointelegraph.com/news/bitcoin-a-long-wayfrom-an-everyday-currency-expert-blog.

Litz, Dominic. 2018. "Risk, Reward, Robo-Advisers: Are Automated Investment Platforms Acting In Your Best Interest? Journal of High Technology Law 18: 367-395.

Lo, Benjamin. 2016. “Online Lenders Shouldn't Get Mad Over Madden,” Journal of Business Entrepreneurship 10: 63-78.

Macey, Jonathan and Caroline Novograd. 2012. "Enforcing Self-Regulatory Organization's Penalties And The Nature of Self-Regulation," Hofstra Law Review 40: 963-1003.

Magnuson, William. 2018. “Regulating Fintech,” Vanderbilt Law Review 71: 1167-1226.

Marinoff, Nick. 2018. "Federal Judge Rules Cryptocurrency MBC Is A Commodity," NASDAQ, September 27, 2018, https://www.nasdaq.com/article/federal-judge-rulescryptocurrency-mbc-is-a-commodity-cm1029363.

Marr, Bernard. 2018. "The 5 Big Problems with Blockchain Everyone Should Be Aware Of," Forbes, February 19, 2018, https://www.forbes.com/sites/bernardmarr/2018/02/19/ the-5-big-problems-with-blockchain-everyone-should-be-aware-of/\#832c6111670c.

Marsh, Alastair and Lily Katz, 2018. "Yale Invests in Crypto Fund That Raised $\$ 400$ Million," Bloomberg, October 5, 2018, https://www.bloomberg.com/news/ articles/2018-10-05/yale-is-said-to-invest-in-crypto-fund-that-raised-400-million.

McCann, Chris. 2017. "Guide to Launching An Initial Coin Offering (ICO)," Medium, October 11, 2017, https://medium.com/@mccannatron/guide-to-launching-an-initialcoin-offering-ico-94587af2c8d5.

McGlone, Mike. 2018. "A U.S. Bitcoin ETF Launch in 2018, Good Luck With That One," Bloomberg, July 23, 2018, https://www.bloomberg.com/professional/blog/u-sbitcoin-etf-launch-2018-good-luck-one/. 
McMillan LLP. 2016. "Fintech at the Crossroads: Regulating The Revolution, Financial Services Bulletin," Updated July 2016, https://mcmillan.ca/Files/191422_Fintech\%20 at\%20the\%20Crossroads\%20-\%20Regulating\%20the\%20Revolution.pdf.

Meyer, David. 2018. "Cryptocurrencies Like Bitcoin Are Commodities, Federal Judge Says. Here's Why That Matters," Fortune, March 7, 2018, http://fortune.com/2018/03/07/ bitcoin-cftc-commodities-coin-drop-markets/.

Mirmazaheri, Shaida. 2016. "How Fintech Firms Provide A New Path To Regulatory Relief For Banks," Review of Banking and Financial Law 36: 175-194.

Mavadiya, Madhvi. 2018. "Why Are Fintechs Not Killing Credit Scoring Agencies?” Forbes, July 30, 2018, https://www.forbes.com/sites/madhvimavadiya/2018/07/30/fintechnot-killing-credit-scoring-agencies/\#33263edc17e2.

McCarthy Tetrault LLP. 2017. "Department of Finance Releases Consultation Paper on New Retail Payments Oversight Framework Providing For Functional Regulation of Payment Service Providers." Updated July 11, 2017. Available from https://www. mccarthy.ca/en/insights/blogs/cyberlex/department-finance-releases-consultationpaper-new-retail-payments-oversight-framework-providing-functional-regulationpayment-service-providers.

McCarthy Tetrault LLP. 2018. "Online Advisers: Stand-Alone Investment Managers or Tools For Portfolio Managers?” May 14, 2018. Available from https://www.mccarthy. $\mathrm{ca} / \mathrm{en} /$ insights/blogs/canadian-securities-regulatory-monitor/online-advisors-standalone-investment-managers-or-tools-portfolio-managers.

Murphy, J. Parker. 2017. "More Sense Than Money: National Charter Option for Fintech firms Is the Right Choice," North Carolina Journal of Law and Technology Online 18: 359-408.

Myers Wood, Julie. 2018. "Regulators Are Catching Up With the Crypto Boom," Forbes, September 27, 2018, https://www.forbes.com/sites/juliemyerswood/2018/09/27/ regulators-are-catching-up-with-the-crypto-boom/\#134b7f331b92.

Nakamoto, Satoshi. 2008. "Bitcoin: A Peer-to-Peer Electronic Cash System," last accessed April 19, 2019, https://bitcoin.org/bitcoin.pdf.

Newcomer, Eric. 2017. "At Uber the limits of the law was something to be tested - now comes the reckoning," Financial Post, October 11, 2017, https://business.financialpost. com/technology/at-uber-the-limits-of-the-law-was-something-to-be-tested-nowcomes-the-reckoning.

New York State Attorney General. 2018. "A.G. Underwood Issues Virtual Markets Integrity Report, Finding Many Platforms Vulnerable To Abusive Trading, Conflicts of Interest, and Other Consumer Risks," September 18, 2018. Available from https://ag.ny.gov/ press-release/ag-underwood-issues-virtual-markets-integrity-report-finding-manyplatforms-vulnerable.

Nonninger, Lea. 2018. "Fintech competition is pushing banks to change strategies," Business Insider, May 23, 2018, https://www.businessinsider.com/fintech-forcingmajor-banking-strategy-shifts-2018-5. 
North American Securities Administrators Association. 2018. "State and Provincial Securities Regulators Conduct Coordinated International Crypto Crackdown," May 21, 2018. Available from http://www.nasaa.org/45121/state-and-provincial-securitiesregulators-conduct-coordinated-international-crypto-crackdown-2/.

O'Connell, Justin. 2016. "What Are The Use Cases For Private Blockchains? The Experts Weigh In," Bitcoin Magazine, June 20, 2016, https://bitcoinmagazine.com/articles/ what-are-the-use-cases-for-private-blockchains-the-experts-weigh-in-1466440884/.

Omarova, Saule T. 2019. "New Tech v. New Deal: Fintech As A Systemic Phenomenon," Yale Journal on Regulation 36, no. 2, forthcoming; Cornell Legal Studies Research Paper No. 18-39. Available from ssrn.com/abstract=3224393.

Ontario Securities Commission. 2017. "CSA Multilateral Notice of Multilateral Instrument 91-102 Prohibition of Binary Options and Related Companion Policy" September 28, 2017. Available from http://www.osc.gov.on.ca/en/SecuritiesLaw_csa_20170927_91102_binary-options.htm.

Ontario Securities Commission, 2015. CSA Staff Notice 31-342, Guidance For Portfolio Managers Regarding Online Advice, Available from http://www.osc.gov.on.ca/en/ SecuritiesLaw_csa_20150924_31-342_portfolio-managers-online-advice.htm.

Ontario Securities Commission. 2017. "OSC Highlights Potential Securities Law Requirements For Businesses Using Distributed Ledger Technologies" March 8, 2017. Available from http://www.osc.gov.on.ca/en/NewsEvents_nr_20170308_oschighlights-potential-securities-law-requirements.htm.

Owram, Kristine. 2018. "Canada's Only Actively Managed Cryptocurrency Fund is 90\% In Cash," Financial Post, July 17, 2018, https://business.financialpost.com/investing/ funds/canadas-only-actively-managed-cryptocurrency-fund-is-90-in-cash.

Pacific Coast Coin Exchange of Canada v. Ontario (Securities Commission), 1977 CarswellOnt 50 (S.C.C.).

Pan, Eric J. 2011. "Structural Reform of Financial Regulation," Transnational Law and Contemporary Problems 19: 796-867.

PWC, 2016. Canadian Banks 2016 Embracing the Fintech Movement, Perspectives on the Canadian Banking Industry, 11.

"Panel on Fintech, Payments and Cryptos," Fintech Unbound: The Cato Summit on Financial Regulation, September 12, 2018. Available from https://www.cato.org/ events/cato-summit-financial-regulation-2018.

Peirce, Hester. 2018. "Keynote Address," (Speech, Fintech Unbound: The Cato Summit on Financial Regulation, September 12, 2018. Available from https://www.cato.org/ events/cato-summit-financial-regulation-2018.

Perez, Sarah. 2018. “U.S. Banks' Venmo Alternative, Zelle, Moved \$75B Last Year, Says 100,000 People Enroll Daily,” Tech Crunch, January 29, 2018, https://techcrunch. com/2018/01/29/u-s-banks-venmo-alternative-zelle-moved-75b-last-year-says100000 -people-enroll-daily. 
Petrou, Karen. 2018. "The Crisis Next Time: The Risk of New-Age Fintech and the LastCrisis Financial Regulation,” Federal Financial Analytics Research Report, September 6, 2018, http://www.fedfin.com/images/stories/client_reports/FedFin\%20Policy\%20 Paper\%20on\%20The\%2ORisk\%20of\%20New-Age\%2OFintech\%2Oand\%2OLastCrisis\%20Financial\%20Regulation.pdf.

Pew Research Center. 2018. "Internet and Technology Mobile Fact Sheet." Updated February 5, 2018. Available from http://www.pewinternet.org/fact-sheet/mobile/.

Popper, Nathaniel. 2017. "An Explanation of Initial Coin Offerings," The New York Times, October 27, 2017, https://www.nytimes.com/2017/10/27/technology/what-is-aninitial-coin-offering.html.

Rastello, Sandrine. 2018. "Desmarais scion says Canada's fintech lag could hurt banks abroad," BNN Bloomberg, October 31, 2018, https://www.bnnbloomberg.ca/ desmarais-scion-says-canada-fintech-lag-could-hurt-banks-abroad-1.1161268.

Reiners, Lee. 2018. "How Regulators Are Responding To Fintech,” Duke Global Financial Markets Centre FinReg Blog, June 29, 2018, https://sites.duke.edu/ thefinregblog/2018/06/29/how-regulators-are-responding-to-fintech/.

Reynard, Cherry. 2018. "The 10 Most Popular Cryptocurrencies In 2018," The Telegraph, May 25, 2018, https://www.telegraph.co.uk/technology/digital-money/top-10popular-cryptocurrencies-2018/.

Roberts, Jeff John. 2017. "Canada Pours Cold Water on Initial Coin Offerings," Fortune, August 28, 2017, http://fortune.com/2017/08/28/canada-ico/.

Roberts, Jeff John. 2018. "The SEC's Big Digital Coin Ruling: What It Means," Fortune, July 26, 2017, http://fortune.com/2017/07/26/sec-icos/.

Rooney, Kate. 2018. "After The Crisis, A New Generation Puts Its Trust in Tech Over Traditional Banks," CNBC, September 14, 2018, https://www.cnbc.com/2018/09/14/ a-new-generation-puts-its-trust-in-tech-over-traditional-banks.html.

Rooney, Kate. 2018. "SEC Director 'underwhelmed' by rate of cryptocurrency exchanges self-reporting," CNBC, June 6, 2018, https://www.cnbc.com/2018/06/06/secunderwhelmed-by-rate-of-cryptocurrency-exchanges-self-reporting.html.

Rooney, Kate. 2018. "SEC Takes First Action Against A Crypto Hedge Fund," CNBC, September 11, 2018, https://www.cnbc.com/2018/09/11/sec-takes-first-actionagainst-a-crypto-hedge-fund.html.

Rooney, Kate. 2018 "Your Guide To Cryptocurrency Regulations Around The World and Where They Are Headed," CNBC, 27 March 2018, https://www.cnbc.com/2018/03/27/ a-complete-guide-to-cyprocurrency-regulations-around-the-world.html.

Rosner, Marcel T. and Andrew Kang. 2016. "Understanding and Regulating Twenty-First Century Payment Systems: The Ripple Case Study,” Michigan Law Review 114: 649-681.

Ross, Elizabeth Sara. 2017. "Nobody Puts Blockchain In a Corner: The Disruptive Role of Blockchain Technology In The Financial Services Industry And Current Regulatory Issues," Catholic University Journal of Law and Technology 25: 353-386. 
Russo, Camila. 2018. “Goldman Sachs Alum's Crypto Fund Expands Even As Markets Tumble," Bloomberg, September 17, 2018, https://www.bloomberg.com/news/ articles/2018-09-17/goldman-sachs-alumni-s-crypto-fund-increases-staff-amid-rout.

Saul, Ben and Margaux Curie. 2018. "FinTech Regulation in the US: Policy, Implementation, and Future Directions," Payments and Fintech Lawyer 15. Available from https://www.whitecase.com/sites/whitecase/files/files/download/publications/ fintech-regulation-in-the-us-policy-implementation-and-future-directions.pdf.

Sakovich, Julia. 2018. "Coinsquare Launches Two New Funds Becoming Canada's Newest ETF Provider,” Coinspeaker, September 24, 2018, https://www.coinspeaker. com/2018/09/24/coinsquare-launches-two-new-funds-becoming-canadas-newestetf-provider/\#.

Sale, Elizabeth. 2018. "Regulatory and Supervisory Rules for Banks - Office of Superintendent of Financial Institutions," International Banking Law and Regulation 8, no.20: 1-9.

Savage, Lawrie. 2014. "From Trial to Triumph: How Canada's Past Financial Crisis Helped Shape A Superior Regulatory System," SPP Research Papers, University of Calgary, School of Public Policy 7, no. 15: 1-53.

Savoie, Robert and Philip Hoffman. 2018. "Marketplace Lending and Fintech: The States Object," Business Law 73: 509-516.

Schroeder, Pete. 2018. "U.S. Regulator Urges Registration of Cryptocurrency Exchanges," Reuters, March 7, 2018, https://www.reuters.com/article/us-usa-sec-crypto/u-sregulator-urges-registration-of-cryptocurrency-exchanges-idUSKCN1GJ2PB.

SEC v. W.J. Howey Co., 328 U.S. 293, 301 (1946).

SEC v. Edwards, 540 U.S. 389, 393 (2004).

Shakow, David. 2018. "The Tao of the DAO: Taxing an Entity that Lives on a Blockchain" Tax Notes 160, 2018: 929, https://ssrn.com/abstract=3247155.

Stanley, Aaron. 2018. "5 Takeaways From The GAO Fintech Report," Forbes, March 31, 2018, https://www.forbes.com/sites/astanley/2018/03/31/five-takeaways-from-thegao-fintech-report/\#4b9eOcfd1db5.

Statista. 2019. "Number of Smartphone Users in Canada from 2013 to 2022," accessed April 13, 2019, https://www.statista.com/statistics/467190/forecast-of-smartphoneusers-in-canada/.

Stern, Gary. 2017. “Can Regulators Keep Up With Fintech?” Yale Insights, Updated December 13, 2017, https://insights.som.yale.edu/insights/can-regulators-keep-upwith-fintech.

Stikeman Elliot LLP. 2018. "Fintech In Canada," Lexology, October 28, 2018. Available from https://www.stikeman.com/en-ca/kh/guides/Fintech-in-Canada.

Surujnath, Ryan. 2017. "Off The Chain! A Guide To Blockchain Derivatives Markets And The Implications On Systemic Risk," Fordham Journal of Corporate and Financial law 22: 257-304. 
Schwarcz, Steven L. 2009. "Regulating Complexity in Financial Markets," Washington University Law Review 87: 211-267.

Tcherepnin v. Knight, 389 U.S. 332 (1967).

Thompson Coburn LLP. 2018. "Virtual Currencies in the USA," Lexology, June 6, 2018. Available from https://www.lexology.com/library/detail.aspx?g=71b4767c-3b6a4f33-a2ba-Oeda39aa1414.

Tonkovic, Rodney F. 2018. "Commissioner Peirce Suggests Regulators Should Leave Room For Innovation," Securities and Exchange Communications Today, 2267086 (C.C.H.) 2018 WL 2267086.

Tweddle, Kevin. 2018. "Doomed? Fintech Partnerships Are Vital," American Banker, July 10, 2018, https://www.americanbanker.com/opinion/doomed-fintechpartnerships-are-vital.

United Housing Fund Inc. v. Forman, 421 U.S. 837, 852-53 (1975).

U.S. Commodity Futures Trading Commission. 2018. "CFTC Staff Issues Advisory For Virtual Currency Products, May 21, 2018. Available from https://www.cftc.gov/ PressRoom/PressReleases/7731-18.

U.S. Commodity Futures Trading Commission. 2017. "CFTC Statement on SelfCertification of Bitcoin Products By CME, CFE and Cantor Exchange," Release Number 7654-17, December 1, 2017. Available from https://www.cftc.gov/ PressRoom/PressReleases/pr7654-17.

U.S. Commodity Futures Trading Commission. 2018. "CFTC Grants DCO Registration to LedgerX LLC" July 24, 2017. Available from https://www.cftc.gov/PressRoom/ PressReleases/pr7592-17.

U.S Commodity Futures Trading Commission. 2018. "Federal Court in New York Enters Preliminary Injunction Order Against Patrick K. McDonnell and his Company Cabbagetech, Corp. D/B/A Coin Drop Markets in Connection with Fraudulent Virtual Currency Scheme," March 6, 2018. Available from https://www.cftc.gov/PressRoom/ PressReleases/pr7702-18.

U.S. Commodity Futures Trading Commission. 2018. “LabCFTC,” https://www.cftc.gov/ LabCFTC/index.htm, accessed September 26, 2018.

U.S. Commodity Futures Trading Commission. 2018. "US CFTC and UK FCA Sign Arrangement To Collaborate on Fintech Innovation" accessed February 19, 2018, https://www.cftc.gov/PressRoom/PressReleases/pr7698-18.

U.S. Consumer Financial Protection Bureau, “Project Catalyst,” https://www. consumerfinance.gov/about-us/project-catalyst/, accessed February 25, 2019.

U.S. Department of The Treasury, 2018. A Financial System That Creates Economic Opportunities, Nonbank Financials, Fintech and Innovation. Available from https://home.treasury.gov/sites/default/files/2018-07/A-Financial-System-thatCreates-Economic-Opportunities---Nonbank-Financi....pdf. 
U.S. Financial Crimes Enforcement Network, 2013. "Application of FinCEN's Regulations To Persons Administering, Exchanging, or Using Virtual Currencies," last updated March 18, 2013, https://www.fincen.gov/sites/default/files/shared/FIN-2013-G001.pdf.

U.S. Government Accountability Office, 2018. "Financial Technology: Additional Steps By Regulators Could Better Protect Consumers and Aid Regulatory Oversight." Available from https://www.gao.gov/products/GAO-18-254.

U.S. Office of the Comptroller of the Currency, "OCC Begins Accepting National Bank Charter Applications From Financial Technology Companies," July 31, 2018. Available from https://www.occ.gov/news-issuances/news-releases/2018/nr-occ-2018-74.html.

U.S. Office of the Comptroller of the Currency, "Responsible Innovation," Available from https://www.occ.treas.gov/topics/responsible-innovation/index-innovation.html, accessed February 25, 2019.

U.S. Securities and Exchange Commission. 2017. "Report of Investigation Pursuant to Section 21(a) of the Securities Exchange Act of 1934: The DAO," Securities Act Release No. 81207, July 25, 2017.

U.S. Securities and Exchange Commission. 2018. "SEC Charges Two Robo-Advisers With False Disclosures," December 21, 2018. Available from https://www.sec.gov/news/ press-release/2018-300.

Van Loo, Rory. 2018. "Making Innovation More Competitive: The Case Of Fintech,” UCLA Law Review 65: 232-279.

Van Loo, Rory. 2017. "Rise of the Digital Regulator," Duke Law Journal 66: 1267-1329.

Vartanian, P. 2016. “Time To Adjust The Regulatory Diet: Fewer Rules, More Principles," American Banker, December 27, 2016, https://www.americanbanker.com/opinion/ time-to-adjust-the-regulatory-diet-fewer-rules-more-principles.

Verhage, Julie. 2017. "Bitcoin's Epic Rise Leaves Late-1990s Tech Bubble in the Dust," Bloomberg, August 29, 2017, https://www.bloomberg.com/news/ articles/2017-08-29/bitcoin-s-epic-rise-leaves-late-1990s-tech-bubble-in-the-dust.

Vigna, Paul. 2019. "Most Bitcoin Trading Faded by Unregulated Exchanges, Study Finds," The Wall Street Journal, March 22, 2019, https://www.wsj.com/articles/most-bitcointrading-faked-by-unregulated-exchanges-study-finds-11553259600.

Vigna, Paul. 2018. "Winklevoss Effort to Self-Regulate Cryptocurrency Gets Members," The Wall Street Journal, August 20, 2018, https://www.wsj.com/articles/winklevosseffort-to-self-regulate-cryptocurrency-gets-members-1534804308.

Wada, Takahiko. 2018. "Financial Crime Task Force Eyeing Binding Crypto Exchange Rules: Japan Official," Reuters, June 12, 2018, https://www.reuters.com/article/uscryptocurrency-regulations-fatf/financial-crime-task-force-eyeing-binding-cryptoexchange-rules-japan-official-idUSKBN1J80UZ.

Waddell, Melanie. 2018. "SEC's Stein Wants More Cyber Rules For Advisors, BDs," ThinkAdvisor, October 1, 2018, https://www.thinkadvisor.com/2018/10/01/secs-steinwants-more-cyber-rules-for-advisors-bds/?slreturn=20180902093243. 
Walch, Angela. 2017. "The Path of the Blockchain Lexicon (And The Law)," Review of Banking and Financial Law 36: 713-765.

Walker, George. 2017. "Financial Technology Law - A New Beginning And A New Future," International Law 50: 137-215.

Walsh, Ben. 2018. "Fintech Firms Are Getting Closer To Being Banks In Everything But Name," Barron's, August 6, 2018, https://www.barrons.com/articles/fintech-firmsare-getting-closer-to-being-banks-in-everything-but-name-1533567415.

Watson, Charlotte and Alex LaPlante. 2018. An Overview of Fintech in Canada, Global Risk Institute, Financial Innovation Series, 4 (March 2018). Available from https://globalriskinstitute.org/publications/an-overview-of-fintech-in-canada/.

Weizhan, Tan. 2018. "Cryptocurrency Regulation Requires A ‘Do No Harm' Approach, US Regulator Says," CNBC, September 14, 2018, https://www.cnbc.com/2018/09/14/dono-harm-in-regulating-cryptocurrencies-but-be-vigilant-cftc.html.

Whitestone, Deanna. 2005. "The Response To Enron in the United States and Canada: Are Principles-Based Accounting Standards More Effective at Preventing Financial Fraud?" Southwest Journal of Law and Trade America 11: 381-399.

Williams, Sean. 2017. "5 Big Advantages of Blockchain, and 1 Reason To Be Very Worried," The Motley Fool. December 11, 2017, https://www.fool.com/investing/2017/12/11/5big-advantages-of-blockchain-and-1-reason-to-be.aspx.

Witkowski, Rachel. 2018. "Square Quietly Withdraws Bank Application," American Banker, July 5, 2018, https://www.americanbanker.com/news/square-quietly-withdrawsbank-application.

World Bank Group. 2018. "Fintech and Financial Inclusion," accessed October 3, 2018, http://pubdocs.worldbank.org/en/877721478111918039/breakout-DigiFinanceMcConaghy-Fintech.pdf.

Zetzsche, Dirk A. et al. 2017. "Regulating A Revolution: From Regulatory Sandboxes To Smart Regulation," Fordham Journal of Corporate and Financial Law, 23: 31-102.

Zochodne, Geoff. 2018. "In-person banking soon to be a rarity, CIBC CEO says, as customers continue to migrate online," Financial Post, September 27, 2018, https://business.financialpost.com/news/fp-street/in-person-banking-soon-to-be-ararity-cibc-ceo-says-as-customers-continue-to-migrate-online. 



\title{
ABOUT THE SCHOOL OF PUBLIC POLICY
}

The School of Public Policy has become the flagship school of its kind in Canada by providing a practical, global and focused perspective on public policy analysis and practice in areas of energy and environmental policy, international policy and economic and social policy that is unique in Canada.

The mission of The School of Public Policy is to strengthen Canada's public service, institutions and economic performance for the betterment of our families, communities and country. We do this by:

- Building capacity in Government through the formal training of public servants in degree and non-degree programs, giving the people charged with making public policy work for Canada the hands-on expertise to represent our vital interests both here and abroad;

- Improving Public Policy Discourse outside Government through executive and strategic assessment programs, building a stronger understanding of what makes public policy work for those outside of the public sector and helps everyday Canadians make informed decisions on the politics that will shape their futures;

- Providing a Global Perspective on Public Policy Research through international collaborations, education, and community outreach programs, bringing global best practices to bear on Canadian public policy, resulting in decisions that benefit all people for the long term, not a few people for the short term.

The School of Public Policy relies on industry experts and practitioners, as well as academics, to conduct research in their areas of expertise. Using experts and practitioners is what makes our research especially relevant and applicable. Authors may produce research in an area which they have a personal or professional stake. That is why The School subjects all Research Papers to a double anonymous peer review. Then, once reviewers comments have been reflected, the work is reviewed again by one of our Scientific Directors to ensure the accuracy and validity of analysis and data.

\author{
The School of Public Policy \\ University of Calgary, Downtown Campus \\ 906 8th Avenue S.W., 5th Floor \\ Calgary, Alberta T2P $1 \mathrm{H} 9$ \\ Phone: 4032103802
}

\section{DISTRIBUTION}

Our publications are available online at www.policyschool.ca.

\section{DISCLAIMER}

The opinions expressed in these publications are the authors' alone and therefore do not necessarily reflect the opinions of the supporters, staff, or boards of The School of Public Policy.

\section{COPYRIGHT}

Copyright (C) Clements 2019. This is an open-access paper distributed under the terms of the Creative Commons license CC BY-NC 4.0, which allows non-commercial sharing and redistribution so long as the original author and publisher are credited.

\section{ISSN}

ISSN 2560-8312 The School of Public Policy Publications (Print) ISSN 2560-8320 The School of Public Policy Publications (Online)

\section{DATE OF ISSUE}

August 2019

\section{MEDIA INQUIRIES AND INFORMATION}

For media inquiries, please contact Morten Paulsen at 403-220-2540. Our web site, www.policyschool.ca, contains more information about The School's events, publications, and staff.

\section{DEVELOPMENT}

For information about contributing to The School of Public Policy, please contact Catherine Scheers by telephone at 403-210-6213 or by e-mail at catherine.scheers@ucalgary.ca. 


\section{RECENT PUBLICATIONS BY THE SCHOOL OF PUBLIC POLICY}

UNDERSTANDING CONSULTATION AND ENGAGEMENT WITH INDIGENOUS PEOPLES IN RESOURCE DEVELOPMENT https://www.policyschool.ca/wp-content/uploads/2019/07/Indigenous-Consultation-Boyd-Lorefice-final2.pdf Brendan Boyd and Sophie Lorefice | August 2019

WHERE IN THE WORLD ARE CANADIAN OIL AND GAS COMPANIES? 2017

https://www.policyschool.ca/wp-content/uploads/2019/07/Where-in-the-World-2017-Larson.pdf Braeden Larson | July 2019

\section{TRADE POLICY TRENDS: BREXIT: IMPLICATIONS FOR CANADA-UK TRADE}

https://www.policyschool.ca/wp-content/uploads/2019/07/Trade-Policy-Trends-Brexit-final.pdf Dylan Klemen and Eugene Beaulieu | July 2019

\section{SOCIAL POLICY TRENDS: FINANCIAL SUPPORT FOR REFUGEES AND ASYLUM SEEKERS}

https://www.policyschool.ca/wp-content/uploads/2019/07/Financial-Supports-for-Refugees-and-Asylum-Seekers-FINAL-version.pdf Robert Falconer | July 2019

\section{ENERGY AND ENVIRONMENTAL POLICY TRENDS: OUR PLANET IN 2040: COMPARING WORLD ENERGY OUTLOOKS}

https://www.policyschool.ca/wp-content/uploads/2019/07/Energy-Trends-World-Energy-Outlooks-final-2.pdf G. Kent Fellows, Victoria Goodday, Rabia Ladha and Jennifer Winter | July 2019

HISTORY OF DEVELOPMENTAL DISABILITY POLICY IN ALBERTA

https://www.policyschool.ca/wp-content/uploads/2019/07/History-of-Disability-Sonpal-Valias.pdf Nilima Sonpal-Valias | July 2019

THE URBAN POLICY CONTEXT IN MEDIUM-SIZED EUROPEAN METROPOLITAN AREAS

https://www.policyschool.ca/wp-content/uploads/2019/07/Mid-Sized-Cities-Barati-Stec.pdf Izabella Barati-Stec | July 2019

TAX POLICY TRENDS: CORPORATE TAX POLICY: ALBERTA GOES ITS OWN WAY

https://www.policyschool.ca/wp-content/uploads/2019/06/TPT-June-AB-Corporate-Tax-METR.pdf Philip Bazel and Jack Mintz | June 2019

REFORMING THE FEDERAL FISCAL STABILIZATION PROGRAM

https://www.policyschool.ca/wp-content/uploads/2019/06/Fiscal-Stabilization-Dahlby-final2.pdf Bev Dahlby | June 2019

SOCIAL POLICY TRENDS: MARITAL STATUS OF THOSE IN POVERTY

http://www.policyschool.ca/wp-content/uploads/2019/06/Social-Policy-Trends-AB-Deep-Pov-Dutton.pdf Daniel Dutton | June 2019

CYBERATTACK: WHAT GOES AROUND, COMES AROUND

http://www.policyschool.ca/wp-content/uploads/2019/06/Cyberattack-Barker-final.pdf Ken Barker | June 2019

ENERGY AND ENVIRONMENTAL POLICY TRENDS: WILL ELECTRIC VEHICLE REBATES SPUR WIDESPREAD ADOPTION? http://www.policyschool.ca/wp-content/uploads/2019/05/EEPT-Electrick-Vehicle-Rebates-Shaffer-final.pdf Blake Shaffer | May 2019

SOCIAL POLICY TRENDS: IMMIGRANT RETENTION IN URBAN-RURAL SETTINGS

http://www.policyschool.ca/wp-content/uploads/2019/05/Social-Policy-Trends-Retention-May-2019.pdf Robert Falconer | May 2019 